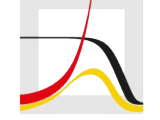

MAX PLANCK INSTITUTE

FOR DEMOGRAPHIC RESEARCH

Konrad-Zuse-Strasse 1 · D-18057 Rostock · Germany · Tel +49 (0) 3812081 - $0 \cdot$ Fax +49 (0) 3812081 - $202 \cdot$ www.demogr.mpg.de

MPIDR Working Paper WP 2022-002 I January 2022

https://doi.org/10.4054/MPIDR-WP-2022-002

\title{
Domestic migration and family formation and dissolution trajectories in Latin America and the Caribbean, 1950-2000
}

Andrés F. Castro Torres I castro@demogr.mpg.de

This working paper has been approved for release by: Natalie Nitsche (nitsche@demogr.mpg.de),

Deputy Head of the Laboratory of Fertility and Well-Being.

(c) Copyright is held by the authors.

Working papers of the Max Planck Institute for Demographic Research receive only limited review. Views or opinions expressed in working papers are attributable to the authors and do not necessarily reflect those of the Institute. 


\title{
Domestic migration and family formation and dissolution trajectories in Latin America and the Caribbean, 1950-2000
}

\begin{abstract}
Due to the importance of urbanization for the $20^{\text {th }}$-century demographic changes in Latin America and the Caribbean (LACar), scholarly research on domestic migration and family has overly focused on fertility differentials by migration status in urban areas. According to this literature, there exists a robust negative correlation between internal migration and fertility. However, this research has overlooked how this relationship varies across migration flows other than rural-to-urban, and according to women's age at migration and social class. Additionally, previous research has not paid enough attention to the family formation and dissolution trajectories underlying the lower fertility of rural migrants. I use a life-course inductive approach to examine these overlooked aspects among women from 10 LACar countries. Using retrospective information on their childbearing and marital histories collected by the Demographic and Health Surveys, I build an eight-category typology of family paths and look at the conditional distribution of this typology by to women's age at migration, educational attainment, and origin/destination area. This examination demonstrates that social class is the primary differentiation axis of family formation and dissolution trajectories, and that low-class young rural migrants played a crucial role on the demographic transformations that occurred in the region from 1950 to 2000.
\end{abstract}




\section{Introduction}

There is a mismatch between the potential role of internal migration on family formation dynamics and the scholarly attention that has been devoted, especially in recent years, to the examination of union formation, fertility, and marriage patterns among domestic migrants (Portes, 2010). Besides being more prevalent than international migration, internal migration is less selective, and it tends to last longer than international, meaning that internal migrants are more likely to stay at the destination. Therefore internal migration is a crucial factor for understanding family change (Montgomery et al., 2003; Dyson, 2011). The movement of a large proportion of socioeconomic and demographically diverse people can significantly shape the demographic traits of family formation processes in societies, i.e., the types of unions, their timing, their stability and duration, and the resulting family size.

This was the case of Latin America and Caribbean (LACar) societies during the second half of the $20^{\text {th }}$ century, where internal migration was more prevalent and less selective than international. Distances for domestic moves were shorter, migration costs were lower, and constraints were lesser than for international migration (e.g., no visa requirements or work permissions). These lower migration costs made internal migration flows much more diverse than international emigration flows in terms of the socioeconomic characteristics of the migrants, the multiplicity of moves, and the reasons to migrate. Also, due to its tendency to be permanent, internal migration was a significant contributor to sustained processes of societal change, including urbanization, fertility decline, and family change (Davis and Casis, 1946; Ebank, 1993; Guzmán et al., 2006). 
Despite the extensive documentation of family and fertility outcomes by internal migration status in LACar countries for this period (1950-2000), there is a dearth of research on how internal migration relates to the family formation and dissolution paths that produced these outcomes.

The switch in focus from the study of outcomes/events (e.g., births, unions, divorces) to the study of processes (i.e., family formation and dissolution trajectories) is beneficial for revising the relationship between migration and family for two reasons. First, individuals' life courses are a more comprehensive unit of analysis than separated events; individuals live full life histories of interconnected transitions, including the potential absence of some of them (Billari, 2001; Macmillan and Copher, 2005). Second, trajectory-based studies are well-suited to describe heterogeneity as they rely on statistical methods tailored to describing the variability across units of analysis that comprise life-course processes (Cornwell, 2015).

In this study, I show that a trajectory-based approach complements single-event studies by adding explicit empirical content to the relationship between migration and family formation and dissolution. I do this by examining the family formation and dissolution trajectories (family trajectories herein) of LACar women interviewed by the Demographic and Health Surveys (DHS) in Bolivia, Brazil, Colombia, Dominican Republic, Guatemala, Haiti, Mexico, Nicaragua, Paraguay, and Peru from 1986 to 2012.

Using cluster analysis techniques, I build an eight-category typology for women's family trajectories. I compare the distribution of the typology according to women's childhood place of residence (urban vs. rural), current area of residence (large cities, urban areas, and rural areas), educational attainment (as a proxy for social class), and age at migration. These examinations show that social class is the primary axis of differentiation of family trajectories and that 
migration is associated with more substantial disruptions for the family paths of low-class young migrant women compared to high-class and adult migrants.

\section{Explanations for non-migrant/migrant differences in fertility}

Most of the literature regarding differences in family outcomes by migration status concentrates on fertility differentials. Since the classic work of Goldberg (1959) on the 'Two-generations Urbanites,' and until the mid-1980s, the study of the relationship between domestic migration and fertility flourished. The perspectives of urban growth in low- and middle-income countries (LMIC) encouraged researchers to measure the contribution of internal migrants to urban growth, and therefore to examine the relationship between migration and reproductive behavior (Macisco and Myers, 1975; Zárate and Unger De Zárate, 1975; Preston, 1979). These studies pointed out the critical aspects of the negative relationship between fertility and internal migration including the selectivity of migrants, the processes of disruption and adaptation that migration entails, and how the relative importance of these processes differ according to countries' level of urbanization (Goldstein, 1973; Martine, 1975; Goldstein and Goldstein, 1981; Hervitz, 1985).

The period between the mids-1990 and the 2000s witnessed a revival of scholarly interest on internal migration and fertility in LMICs. These studies include the Philippines, Turkey, Guatemala, Brazil, Thailand, Cameroon, and other Sub-Saharan African nations (Lee, 1992; Brockerhoff and Yang, 1994; Lindstrom, 2003; Jensen and Ahlburg, 2004; Lindstrom and Hernández, 2006; Eryurt and KOÇ, 2012).

Migrant-non-migrant differences in fertility outcomes - in particular, the lower fertility of ruralto-urban migrants compared to non-migrants in rural areas-have been explained in terms of 
four hypotheses, often presented as competing explanations: selection, socialization, disruption, and adaptation. The first two explanations focus on conditions before migration, such as family norms and values learned during childhood (socialization) and the less family-oriented attitudes or anticipatory behavior of migrants (selection). The other two explanations (disruption, and adaptation) emphasize how changing circumstances caused by migration could lead to a disruption in migrants' family trajectories, or how these circumstances lead them to adapt their behaviors to socioeconomic conditions at destination (e.g., higher childrearing cost at destination).

The reconciliation of these results is difficult due to differences across data sources and methodologies (Zárate and Unger De Zárate, 1975). However, an overarching conclusion is that the validity of each of these four hypotheses and the extent to which they produce significant differences in fertility by migration status are context-dependent (Kulu, 2005).

\section{Context of study}

In LACar, urbanization was paralleled by rapid family change after 1950 (Ducoff et al., 1965; Elizaga, Lee and Arias, 1965; Dufour and Piperata, 2004; Rodríguez Vignoli and Busso, 2009). Between 1950 and 1990, fertility declined from above six children per woman to 3.5, and cohabitation and marital instability increased (Brea, 2003; Arriagada, 2007; Esteve and Lesthaeghe, 2016). Only the mean ages at first birth and first marriage remained relatively stable; while low-class women were accelerating the transition to childbearing, high-class women continued to postpone this transition (Pantelides, 2004; Rodríguez Vignoli, 2010; Esteve and Florez-Paredes, 2014). 
Internal migration - voluntary and forced-boosted urbanization all over the region with different rapidity across countries (Bernard et al., 2017). Government-led initiatives towards industrialization actively promoted rural-to-urban migration, especially during the 1950-1970 period (Bethell, 1998; Arnaut, 2010). Despite cross-national differences in the relative success of these initiatives, a common trend of decline in the proportion of people living in rural areas is common to all LACar countries. By the end of the century, the share of the population living in rural areas was, for the most part of them, below 30\% (United Nations, 2018).

Internal migration flows were not unidirectional. A considerable part of the population moved from urban to rural areas, between cities, and between rural areas. These latter flows were especially prevalent after 1970, when national economies abandoned the import substitutions models, and structural economic reforms imposed significant restrictions on social expenditures (Baer, 1972). Rural areas and small cities were negatively affected by these changes as incentives to invest in disperse and low-density areas have always been low (Sassen-Koob, 1984; Babb, 2005). These reforms fueled migration flows in multiple directions as some regions, and economic sectors benefited more than others creating the need and opportunities for people to migrate in search of better economic prospects. Additionally, in countries with long-lasting armed conflicts (Mexico, El Salvador, Nicaragua, Colombia, and Peru), internally displaced populations moved across different places to escape violence, primarily concentrated in rural areas (Alvarado and Massey, 2010).

This context offers three advantages to extend our understanding of the relationship between internal migration and family formation and dissolution trajectories. First, birth cohorts that transitioned to adulthood during this period have already exited (or are close to exit) reproductive ages, which allows studying completed family trajectories. Second, taking family trajectories as 
objects of study contributes to qualifying our accounts of demographic change by extending previous research on fertility to interconnected family events. Third, the patterns that emerge from a variegated sample of countries and cohorts would reflect the overarching mechanisms behind the interaction between the migration experience and family formation dynamics.

\section{Data, measures, and methods}

Analytical sample from the Demographic and Health Surveys (DHS)

I use data from 27 waves of the DHS in 10 LACar countries; DHS are nationally representative of women of reproductive ages (15 to 49). I select surveys that maximize geographical and temporal coverage, and according to the availability of information regarding childhood place of residence and the years of residence in the place of the interview. I focus on women age 39 to 49 , i.e., women who were born between 1937 and 1973 and whose family trajectories unfolded throughout the second half of the twentieth century. ${ }^{1}$

Table 1 displays the sample size by country and current place of residence. This latter variable is coded into three categories: large cities, urban areas, and rural areas. I use the DHS-countryspecific definition of rural and urban areas, and I code the capital city of each country plus cities of more than 500 thousand inhabitants as large cities. I separate these cities because they differ from other urban areas in aspects that could affect family trajectories. These include the prevalence of a service economy, higher costs of living, better access to basic services, and fewer opportunities to reconcile childrearing and work (Montgomery et al., 2003).

\footnotetext{
1 The survey years for each country are Bolivia $(1989,2003,2008)$, Brazil $(1986,1991,1996)$, Colombia (1986, 1990, 1995, 2005), Dominican Republic (1986, 1991, 1996, 1999, 2002), Guatemala (1987), Haiti (1994), Mexico (1987), Nicaragua (1998, 2001), Paraguay (1991), and Peru (1991, 1996, 2000, 2004, 2009 -12)
} 
Table 1: Analytical sample by country and current place of residence, and number of waves per country

\begin{tabular}{lrrrrr}
\hline \multirow{2}{*}{ Country } & \multicolumn{3}{c}{ Place of residence } & \multirow{2}{*}{ Total } & $\begin{array}{c}\text { Number } \\
\text { of waves }\end{array}$ \\
\cline { 2 - 3 } & Large cities & Urban & Rural & & $\begin{array}{r}\text { Non } \\
\text { Bolivia }\end{array}$ \\
Brazil & 2,622 & 2,885 & 3,562 & 9,069 & 3 \\
Colombia & 4,040 & 913 & 1,179 & 5,002 & 3 \\
Dominican Republic & 1,368 & 4,062 & 1,210 & 12,312 & 4 \\
Guatemala & 103 & 132 & 3,796 & 9,580 & 4 \\
Haiti & 454 & 641 & 1,998 & 3,093 & 2 \\
Mexico & 441 & 611 & 643 & 1,695 & 1 \\
Nicaragua & 638 & 2,288 & 2,077 & 5,003 & 2 \\
Paraguay & 293 & 262 & 593 & 1,148 & 1 \\
Peru & 7,179 & 25,305 & 18,032 & 50,516 & 6 \\
\hline Total & 20,048 & 44,515 & 33,482 & 98,045 & 27 \\
\hline
\end{tabular}

Note: the analytical sample includes women age 39 to 49 who were interviewed by the Demographic and Health Surveys from 1986 to 2012, i.e., the 1937 to 1973 birth cohorts.

Countries are not equally represented in all birth cohorts due to differences in the survey years and the number of waves. This unbalanced composition of the sample may affect the generalizability of the results. To partially counter this effect, I use standardize sampling weights dividing the original sampling weights by the mean sampling weight of each DHS wave, and by the number of waves per country. This weighting strategy reduces the influence of countries with several DHS (e.g., Peru).

In addition, results are consistent when the analysis includes only women from the 1945-1965 birth cohorts. This subsample comprises women from all countries (refer to Table A1 for the sample composition by country and cohort, and Figures A2, A3, and A4 for the summary results). This consistency suggests that results are not driven by one country or by the specific composition of the analytical sample. 


\section{A typology of family formation and dissolution trajectories}

To create the outcome variable: a typology for family formation and dissolution trajectories, I combine factorial and cluster analysis techniques (Pardo and Del Campo, 2007). First, I conduct a multiple correspondence analysis (MCA) on six variables that measure women's family trajectories(Greenacre and Blasius, 2006). These variables are the age at first marriage or union, age at first and last birth, number of children ever born, current marital status, and whether the woman had been in multiple unions or marriages. To make these variables suitable for an MCA, I recoded them into a similar number of categories (Lebart, Morineau and Piron, 1997). Table 2 displays these six variables, their categories, and the cutoff points that I use to categorize the four numerical variables.

Table 2: Variables related to family formation and dissolution trajectories, cutoff points for numerical variables, and categories

\begin{tabular}{|c|c|c|}
\hline Variable & $\begin{array}{c}\text { Nr. of } \\
\text { categories }\end{array}$ & Categories and cutoff points \\
\hline $\begin{array}{l}\text { Age at first } \\
\text { marriage or union }\end{array}$ & 5 & $\begin{array}{l}\text { Never married, Non-adult }(<18) \text {, Adult-early }(18 \text { to } 25) \\
\text { Adult-mid ( } 26 \text { to } 32) \text {, Adult-late }(>32)\end{array}$ \\
\hline Age at first birth & 5 & $\begin{array}{l}\text { Childless, Non-adult ( }<18) \text {, Adult-early (18 to } 25) \text {, } \\
\text { Adult-mid ( } 26 \text { to } 32) \text {, Adult-late }(>32)\end{array}$ \\
\hline Age at last birth & 5 & $\begin{array}{l}\text { Childless, Adult-early (<25), Adult-mid (26 to } 32) \text {, } \\
\text { Adult-late ( } 33 \text { to } 39) \text {, Adult-latest }(>40)\end{array}$ \\
\hline Children ever born & 6 & $\begin{array}{l}\text { Childless, One, Two, Three to Four, Five to Six, } \\
\text { Seven or more }\end{array}$ \\
\hline $\begin{array}{l}\text { Current marital } \\
\text { status }\end{array}$ & 5 & $\begin{array}{l}\text { Never married or in union, In union, Married, } \\
\text { Divorced/Separated, Widow }\end{array}$ \\
\hline $\begin{array}{l}\text { Number of } \\
\text { marriages or unions }\end{array}$ & 3 & $\begin{array}{l}\text { Never married or in union, Once married or in union, } \\
\text { More than once }\end{array}$ \\
\hline
\end{tabular}

Note: The percentage distribution of women across all these variables by country is displayed in Table A2. 
I assess the distribution of the variance across the MCA-dimensions and use those with aboveaverage contributions in a two-step cluster analysis (CA). The two steps of the CA are the Ward method and the K-mean algorithm (Pardo and Del Campo, 2007). This CA approach groups women according to their family trajectories as measured by the variables in Table 2, and summarized by the MCA factorial dimensions. I called this grouping family trajectories typology or family typology for short.

The construction of this typology deserves some conceptual clarifications. The primary purpose of this typology is to examine family formation and dissolution as a process, i.e., as the cumulative occurrence of events over the life course. In that sense, the categories of this typology do not represent the individual experience of any woman or the average woman; these categories represent ideal types, i.e., they are constructs reflecting the connection among family events over the life course. That is the main strength of a typology approach.

However, this typology has some limitations. First, there is some individual-level variability that is left unexplained. Second, the generalizability of this typology is not granted because the grouping is entirely dependent on the variables selected for the MCA. This selection is parsimonious rather than exhaustive as it includes family formation traits that are more likely to be affected by migration (e.g., age at first birth and marital status), and excludes others that may be of lesser importance (e.g., age at first sexual intercourse and birth intervals). Thus, when interpreting the results, it is necessary to keep in mind the proportion of unexplained variability (measured via $\mathrm{R}^{2}$ ), and the fact that the representativeness of the typology is limited to the six variables included in the $\mathrm{MCA} / \mathrm{CA}$.

Measures of migration status, age at migration, and social class 
To measure migration status and women's age at migration, I use the information on the current place of residence (large city, urban area, rural area), childhood place of residence (urban area, rural area), and the number of years women have lived in the place they were interviewed (years since last migration). These three variables allow me to distinguish nine groups of women. Nonmigrant women are those who have lived their entire life in the place they were interviewed (reference group). Migrant women are separated according to their childhood place of residence as women of urban and rural origin, and based on their age at migration in four categories, for a total of eight migrant groups. The four categories for the age at migration are before age 18, 19 to 24,25 to 30 , and after age 30 . These age groups reflect crucial stages in women's transition to adulthood and their autonomy gaining trajectories. Age 18 is the legal age of majority in all these countries for which women who migrated before this age could be considered as dependent migrants. At the other end of the age at migration categories (after age 30), migration occurs after most of the critical transitions to adulthood had taken place, i.e., finishing school, leaving the parental home, entering the job market, to mention a few. These women migrate as autonomous adults. The middle age-at-migration groups are suited to study the connection between migration and family formation, and the potential disruptions that internal mobility entails.

Although this information is not perfect for measuring domestic migration experiences, it is the best available source one can use (Montgomery et al., 2003). The omission of migration moves before the last one, and the potential upward bias in the age at migration could affect the results by diminishing/omitting the significance of the very first migration experience. This omission will be more consequential for women whose most recent migration occurred at adult-late ages compared to women who migrated as young adults because early migration moves are likely to 
be the first. Consequently, the observed patterns in the present analysis should be considered as a conservative estimate of the actual patterns that would emerge if all migration moves were included in the data.

To measure women's social class, I categorize the total years of schooling as lowest (0 to 4), low (5 to 8), medium (9 to 12 ), and high (13 and more). The first category comprises the very bottom-end of LACar social stratification systems. Women with less than five years of schooling are a very negatively selected group. The persistence of this group across cohorts reflects the enduring unequal opportunity structure of LACar countries. Women with 5 to 8 years of schooling have only basic literacy and numeracy skills. No training for the labor market is involved during these school years. Women in the 9 to 12 years of schooling group have a considerable advantage because they finished educational cycles that involve title granting: secondary education diploma (typically after $9^{\text {th }}$ grade) and high school degree (typically after $11^{\text {th }}$ or $12^{\text {th }}$ grade). Formally, a secondary education diploma gives access to the formal labor market and a high school degree to the higher education system. Finally, women with 13 years of schooling or more are the most privileged ones for two reasons. First, they grew up in families and contexts that allowed them to be students (partially dependent) for a very long time. Second, they have the best socioeconomic prospects when entering the labor market, given the rising returns to education in LACar. This interpretation of educational attainment categories in terms of social class is consistent with research on the role of educational systems in LACar societies (Hoffman and Centeno, 2003; Torche, 2014).

Combined, age at migration groups and educational attainment categories define $9 \times 4=36$ groups, observed across three different areas of residence (large cities, urban areas, and rural areas) for a total of $36 \times 3=108$ groups of women. The conditional distribution of the family 
typology in each of these groups is termed family profile. If the family profiles of migrants and non-migrants do not differ, we will conclude that family trajectories and internal migration are independent. On the contrary, if migration and family trajectories are not independent, migrant women should be overrepresented (positive association) or underrepresented (negative association) in certain categories of the family typology.

To show these under- and over-representation of groups across family categories, I apply a Principal Component Analysis (PCA) to a table that appends all the 108 family profiles. The scatterplot of the first two principal components of the columns (family formation categories), and the rows (groups of women) displays the main similarities and discrepancies across family profiles. The proximity between categories of the typology and groups signal positive association, i.e., a higher propensity among women to follow a given family trajectory. The proximity between two groups of women implies resemblance, meaning that groups that are close to one another are likely to follow the same family paths. Finally, the proximity between two categories of the family typology implies that the same groups of women are likely to follow these two categories.

\section{Results}

Descriptive statistics of women's socioeconomic conditions

According to Table 3 , at least $40 \%$ of women in the three areas of residence are domestic migrants; this percentage surpasses $50 \%$ in urban contexts meaning that more than half of the women had domestic migration experience in both urban areas and large cities. 
Table 3: Migration prevalence, educational profiles, and wealth profiles by area of residence, residence during childhood, and age at migration

\begin{tabular}{|c|c|c|c|c|c|c|c|c|c|c|c|c|c|}
\hline \multirow{2}{*}{$\begin{array}{l}\text { Ch. place of } \\
\text { residence }\end{array}$} & \multirow{2}{*}{$\begin{array}{c}\text { Origin and age } \\
\text { at migration }\end{array}$} & \multirow{2}{*}{ Percent } & \multicolumn{5}{|c|}{ Years of schooling } & \multicolumn{6}{|c|}{ Weatlh quintile } \\
\hline & & & $0-4$ & $5-8$ & $9-12$ & $13+$ & Total & 1 st & 2nd & $3 \mathrm{rd}$ & 4th & 5 th & Total \\
\hline \multicolumn{14}{|l|}{ Panel A } \\
\hline Large cities & Non migrant & $\begin{array}{r}\mathbf{4 2 . 2} \\
(2.1)\end{array}$ & $\begin{array}{l}19.3 \\
(4.1)\end{array}$ & $\begin{array}{l}25.2 \\
(4.0)\end{array}$ & $\begin{array}{l}31.1 \\
(2.6)\end{array}$ & $\begin{array}{l}24.5 \\
(4.9)\end{array}$ & 100 & $\begin{array}{l}\mathbf{1 . 7} \\
(0.6)\end{array}$ & $\begin{array}{r}\mathbf{6 . 3} \\
(1.6)\end{array}$ & $\begin{array}{r}\mathbf{1 3 . 4} \\
(1.3)\end{array}$ & $\begin{array}{r}\mathbf{2 6 . 4} \\
(1.1)\end{array}$ & $\begin{array}{r}\mathbf{5 2 . 2} \\
(2.9)\end{array}$ & 100 \\
\hline $\begin{array}{l}\text { Urban origin } \\
(40.9 \%)\end{array}$ & $<18$ & $\begin{array}{l}13.6 \\
(0.9)\end{array}$ & $\begin{array}{l}26.8 \\
(3.8)\end{array}$ & $\begin{array}{l}28.8 \\
(2.5)\end{array}$ & $\begin{array}{l}27.0 \\
(2.5)\end{array}$ & $\begin{array}{l}17.4 \\
(3.0)\end{array}$ & 100 & $\begin{array}{r}1.3 \\
(0.4)\end{array}$ & $\begin{array}{r}6.9 \\
(1.3)\end{array}$ & $\begin{array}{l}16.2 \\
(1.8)\end{array}$ & $\begin{array}{l}26.4 \\
(1.6)\end{array}$ & $\begin{array}{l}49.3 \\
(1.9)\end{array}$ & 100 \\
\hline \multirow{7}{*}{$\begin{array}{l}\text { Rural origin } \\
(16.9 \%)\end{array}$} & $19-24$ & $\begin{array}{r}8.7 \\
(0.4)\end{array}$ & $\begin{array}{l}24.9 \\
(3.6)\end{array}$ & $\begin{array}{l}27.9 \\
(2.5)\end{array}$ & $\begin{array}{l}28.9 \\
(2.6)\end{array}$ & $\begin{array}{l}18.3 \\
(2.6)\end{array}$ & 100 & $\begin{array}{r}1.7 \\
(0.4)\end{array}$ & $\begin{array}{r}6.3 \\
(1.1)\end{array}$ & $\begin{array}{l}16.2 \\
(1.6)\end{array}$ & $\begin{array}{l}28.3 \\
(1.2)\end{array}$ & $\begin{array}{l}47.5 \\
(2.1)\end{array}$ & 100 \\
\hline & $25-30$ & $\begin{array}{r}6.7 \\
(0.4)\end{array}$ & $\begin{array}{l}26.5 \\
(4.3)\end{array}$ & $\begin{array}{l}28.5 \\
(3.4)\end{array}$ & $\begin{array}{l}25.9 \\
(2.2)\end{array}$ & $\begin{array}{l}19.1 \\
(3.3)\end{array}$ & 100 & $\begin{array}{r}1.2 \\
(0.6)\end{array}$ & $\begin{array}{r}9.6 \\
(1.8)\end{array}$ & $\begin{array}{l}18.1 \\
(1.0)\end{array}$ & $\begin{array}{l}32.9 \\
(1.9)\end{array}$ & $\begin{array}{l}38.2 \\
(2.8)\end{array}$ & 100 \\
\hline & $>30$ & $\begin{array}{l}11.9 \\
(1.0)\end{array}$ & $\begin{array}{l}30.1 \\
(4.0)\end{array}$ & $\begin{array}{l}26.8 \\
(2.5)\end{array}$ & $\begin{array}{l}24.2 \\
(1.7)\end{array}$ & $\begin{array}{l}18.9 \\
(2.8)\end{array}$ & 100 & $\begin{array}{r}2.9 \\
(0.6)\end{array}$ & $\begin{array}{l}10.3 \\
(2.1)\end{array}$ & $\begin{array}{l}18.0 \\
(1.3)\end{array}$ & $\begin{array}{l}24.8 \\
(1.3)\end{array}$ & $\begin{array}{l}44.0 \\
(3.3)\end{array}$ & 100 \\
\hline & $<18$ & $\begin{array}{r}4.8 \\
(0.6)\end{array}$ & $\begin{array}{l}46.2 \\
(5.4)\end{array}$ & $\begin{array}{l}28.8 \\
(2.4)\end{array}$ & $\begin{array}{l}18.2 \\
(3.3)\end{array}$ & $\begin{array}{r}6.8 \\
(1.8)\end{array}$ & 100 & $\begin{array}{r}2.4 \\
(1.0)\end{array}$ & $\begin{array}{l}10.8 \\
(2.0)\end{array}$ & $\begin{array}{l}21.2 \\
(1.8)\end{array}$ & $\begin{array}{l}33.2 \\
(2.3)\end{array}$ & $\begin{array}{l}32.4 \\
(3.2)\end{array}$ & 100 \\
\hline & $19-24$ & $\begin{array}{r}4.2 \\
(0.5)\end{array}$ & $\begin{array}{l}51.3 \\
(5.9)\end{array}$ & $\begin{array}{l}26.7 \\
(1.7)\end{array}$ & $\begin{array}{l}15.7 \\
(3.8)\end{array}$ & $\begin{array}{r}6.3 \\
(1.6)\end{array}$ & 100 & $\begin{array}{r}3.0 \\
(0.6)\end{array}$ & $\begin{array}{l}10.5 \\
(1.8)\end{array}$ & $\begin{array}{l}24.5 \\
(3.4)\end{array}$ & $\begin{array}{l}31.2 \\
(3.6)\end{array}$ & $\begin{array}{l}30.8 \\
(3.3)\end{array}$ & 100 \\
\hline & $25-30$ & $\begin{array}{r}2.8 \\
(0.4)\end{array}$ & $\begin{array}{l}62.5 \\
(6.1)\end{array}$ & $\begin{array}{l}24.1 \\
(3.7)\end{array}$ & $\begin{array}{r}9.4 \\
(2.3)\end{array}$ & $\begin{array}{r}4.1 \\
(1.5)\end{array}$ & 100 & $\begin{array}{r}5.4 \\
(1.9)\end{array}$ & $\begin{array}{l}17.3 \\
(3.2)\end{array}$ & $\begin{array}{l}23.7 \\
(3.2)\end{array}$ & $\begin{array}{l}32.7 \\
(2.1)\end{array}$ & $\begin{array}{l}20.8 \\
(3.1)\end{array}$ & 100 \\
\hline & $>30$ & $\begin{array}{r}5.2 \\
(0.8)\end{array}$ & $\begin{array}{l}62.5 \\
(5.1)\end{array}$ & $\begin{array}{l}21.1 \\
(2.6)\end{array}$ & $\begin{array}{l}12.0 \\
(2.2)\end{array}$ & $\begin{array}{r}4.4 \\
(0.9)\end{array}$ & 100 & $\begin{array}{r}9.0 \\
(2.0)\end{array}$ & $\begin{array}{l}22.6 \\
(3.1)\end{array}$ & $\begin{array}{l}23.7 \\
(2.1)\end{array}$ & $\begin{array}{l}26.7 \\
(3.4)\end{array}$ & $\begin{array}{l}18.0 \\
(3.0)\end{array}$ & 100 \\
\hline Urban areas & Non migrant & $\begin{array}{r}\mathbf{4 2 . 7} \\
(1.8)\end{array}$ & $\begin{array}{l}26.7 \\
(4.6)\end{array}$ & $\begin{array}{l}27.4 \\
(2.2)\end{array}$ & $\begin{array}{l}27.5 \\
(2.6)\end{array}$ & $\begin{array}{l}18.4 \\
(3.6)\end{array}$ & 100 & $\begin{array}{r}4.3 \\
(0.8)\end{array}$ & $\begin{array}{l}11.9 \\
(1.2)\end{array}$ & $\begin{array}{l}20.7 \\
(0.8)\end{array}$ & $\begin{array}{l}30.0 \\
(0.9)\end{array}$ & $\begin{array}{l}33.1 \\
(1.3)\end{array}$ & $\overline{100}$ \\
\hline \multirow[t]{4}{*}{$\begin{array}{l}\text { Urban origin } \\
(34.1 \%)\end{array}$} & $<18$ & $\begin{array}{r}9.4 \\
(0.8)\end{array}$ & $\begin{array}{r}24.3 \\
(3.1)\end{array}$ & $\begin{array}{c}28.6 \\
(2.0)\end{array}$ & $\begin{array}{l}28.2 \\
(1.9)\end{array}$ & $\begin{array}{l}18.9 \\
(2.9)\end{array}$ & 100 & $\begin{array}{r}2.7 \\
(0.6)\end{array}$ & $\begin{array}{l}10.0 \\
(1.3)\end{array}$ & $\begin{array}{l}20.6 \\
(0.9)\end{array}$ & $\begin{array}{r}29.0 \\
(1.6)\end{array}$ & $\begin{array}{l}37.6 \\
(2.2)\end{array}$ & 100 \\
\hline & $19-24$ & $\begin{array}{r}7.1 \\
(0.6)\end{array}$ & $\begin{array}{l}24.6 \\
(3.1)\end{array}$ & $\begin{array}{l}27.2 \\
(2.0)\end{array}$ & $\begin{array}{l}27.1 \\
(2.2)\end{array}$ & $\begin{array}{l}21.1 \\
(2.3)\end{array}$ & 100 & $\begin{array}{r}2.2 \\
(0.6)\end{array}$ & $\begin{array}{r}8.6 \\
(1.1)\end{array}$ & $\begin{array}{l}21.4 \\
(1.1)\end{array}$ & $\begin{array}{r}28.3 \\
(1.2)\end{array}$ & $\begin{array}{l}39.5 \\
(1.7)\end{array}$ & 100 \\
\hline & $25-30$ & $\begin{array}{r}6.2 \\
(0.4)\end{array}$ & $\begin{array}{l}21.7 \\
(2.8)\end{array}$ & $\begin{array}{l}27.9 \\
(2.6)\end{array}$ & $\begin{array}{l}25.9 \\
(1.7)\end{array}$ & $\begin{array}{l}24.5 \\
(3.9)\end{array}$ & 100 & $\begin{array}{r}2.9 \\
(0.7)\end{array}$ & $\begin{array}{l}10.9 \\
(1.3)\end{array}$ & $\begin{array}{r}20.2 \\
(1.3)\end{array}$ & $\begin{array}{r}28.6 \\
(1.2)\end{array}$ & $\begin{array}{l}37.3 \\
(1.5)\end{array}$ & 100 \\
\hline & $>30$ & $\begin{array}{l}11.3 \\
(0.6)\end{array}$ & $\begin{array}{l}25.1 \\
(2.9)\end{array}$ & $\begin{array}{l}27.8 \\
(2.2)\end{array}$ & $\begin{array}{l}26.8 \\
(1.4)\end{array}$ & $\begin{array}{l}20.3 \\
(3.2)\end{array}$ & 100 & $\begin{array}{r}4.2 \\
(0.6)\end{array}$ & $\begin{array}{l}14.7 \\
(1.1)\end{array}$ & $\begin{array}{l}21.2 \\
(1.7)\end{array}$ & $\begin{array}{c}27.6 \\
(1.0)\end{array}$ & $\begin{array}{l}32.2 \\
(1.7)\end{array}$ & 100 \\
\hline \multirow[t]{4}{*}{$\begin{array}{l}\text { Rural origin } \\
(23.2 \%)\end{array}$} & $<18$ & $\begin{array}{r}5.5 \\
(0.4)\end{array}$ & $\begin{array}{l}46.0 \\
(5.5)\end{array}$ & $\begin{array}{l}30.0 \\
(2.1)\end{array}$ & $\begin{array}{l}16.3 \\
(3.2)\end{array}$ & $\begin{array}{r}7.6 \\
(1.3)\end{array}$ & 100 & $\begin{array}{r}4.7 \\
(1.1)\end{array}$ & $\begin{array}{l}15.0 \\
(1.2)\end{array}$ & $\begin{array}{r}26.0 \\
(1.2)\end{array}$ & $\begin{array}{r}30.0 \\
(1.8)\end{array}$ & $\begin{array}{l}24.3 \\
(2.5)\end{array}$ & 100 \\
\hline & $19-24$ & $\begin{array}{r}4.9 \\
(0.4)\end{array}$ & $\begin{array}{l}52.0 \\
(5.4)\end{array}$ & $\begin{array}{l}27.6 \\
(2.0)\end{array}$ & $\begin{array}{l}13.8 \\
(2.8)\end{array}$ & $\begin{array}{r}6.6 \\
(1.1)\end{array}$ & 100 & $\begin{array}{r}5.3 \\
(1.0)\end{array}$ & $\begin{array}{l}18.3 \\
(1.2)\end{array}$ & $\begin{array}{l}27.3 \\
(1.4)\end{array}$ & $\begin{array}{l}29.4 \\
(1.7)\end{array}$ & $\begin{array}{l}19.7 \\
(2.3)\end{array}$ & 100 \\
\hline & $25-30$ & $\begin{array}{r}4.3 \\
(0.4)\end{array}$ & $\begin{array}{l}50.9 \\
(4.3)\end{array}$ & $\begin{array}{l}28.9 \\
(1.3)\end{array}$ & $\begin{array}{l}14.5 \\
(2.5)\end{array}$ & $\begin{array}{r}5.8 \\
(1.2)\end{array}$ & 100 & $\begin{array}{r}6.3 \\
(0.9)\end{array}$ & $\begin{array}{r}22.4 \\
(1.6)\end{array}$ & $\begin{array}{l}27.6 \\
(2.5)\end{array}$ & $\begin{array}{l}25.6 \\
(1.8)\end{array}$ & $\begin{array}{l}18.2 \\
(2.4)\end{array}$ & 100 \\
\hline & $>30$ & $\begin{array}{r}8.5 \\
(0.6)\end{array}$ & $\begin{array}{l}59.4 \\
(5.6)\end{array}$ & $\begin{array}{l}26.0 \\
(2.8)\end{array}$ & $\begin{array}{r}9.4 \\
(2.0)\end{array}$ & $\begin{array}{r}5.2 \\
(1.0)\end{array}$ & 100 & $\begin{array}{l}11.8 \\
(1.1)\end{array}$ & $\begin{array}{l}26.9 \\
(1.6)\end{array}$ & $\begin{array}{l}27.2 \\
(2.4)\end{array}$ & $\begin{array}{l}21.2 \\
(1.2)\end{array}$ & $\begin{array}{l}12.9 \\
(1.9)\end{array}$ & 100 \\
\hline Rural areas & Non migrant & $\begin{array}{r}\mathbf{5 6 . 8} \\
(2.3)\end{array}$ & $\begin{array}{l}76.8 \\
(4.0)\end{array}$ & $\begin{array}{l}17.3 \\
(2.7)\end{array}$ & $\begin{array}{r}4.5 \\
(1.1)\end{array}$ & $\begin{array}{r}1.3 \\
(0.3)\end{array}$ & 100 & $\begin{array}{l}44.9 \\
(3.7)\end{array}$ & $\begin{array}{l}32.7 \\
(2.3)\end{array}$ & $\begin{array}{l}14.2 \\
(1.1)\end{array}$ & $\begin{array}{r}5.5 \\
(1.0)\end{array}$ & $\begin{array}{r}2.7 \\
(0.9)\end{array}$ & $\overline{100}$ \\
\hline \multirow[t]{4}{*}{$\begin{array}{l}\text { Urban origin } \\
(14.4 \%)\end{array}$} & $<18$ & $\begin{array}{r}2.7 \\
(0.3)\end{array}$ & $\begin{array}{l}64.2 \\
(5.4)\end{array}$ & $\begin{array}{r}24.2 \\
(2.5)\end{array}$ & $\begin{array}{r}8.6 \\
(2.7)\end{array}$ & $\begin{array}{r}3.0 \\
(1.0)\end{array}$ & 100 & $\begin{array}{r}28.4 \\
(2.7)\end{array}$ & $\begin{array}{r}35.7 \\
(3.1)\end{array}$ & $\begin{array}{l}18.4 \\
(2.5)\end{array}$ & $\begin{array}{r}9.3 \\
(1.1)\end{array}$ & $\begin{array}{r}8.2 \\
(2.7)\end{array}$ & 100 \\
\hline & $19-24$ & $\begin{array}{r}3.5 \\
(0.3)\end{array}$ & $\begin{array}{l}54.6 \\
(5.1)\end{array}$ & $\begin{array}{l}27.8 \\
(2.6)\end{array}$ & $\begin{array}{l}13.7 \\
(2.8)\end{array}$ & $\begin{array}{r}3.8 \\
(1.1)\end{array}$ & 100 & $\begin{array}{l}28.1 \\
(2.9)\end{array}$ & $\begin{array}{l}32.0 \\
(3.1)\end{array}$ & $\begin{array}{l}23.9 \\
(2.0)\end{array}$ & $\begin{array}{r}9.9 \\
(2.0)\end{array}$ & $\begin{array}{r}6.2 \\
(2.0)\end{array}$ & 100 \\
\hline & $25-30$ & $\begin{array}{r}2.8 \\
(0.2)\end{array}$ & $\begin{array}{r}55.8 \\
(4.9)\end{array}$ & $\begin{array}{l}26.8 \\
(2.6)\end{array}$ & $\begin{array}{l}11.1 \\
(2.3)\end{array}$ & $\begin{array}{r}6.4 \\
(2.0)\end{array}$ & 100 & $\begin{array}{l}31.7 \\
(4.2)\end{array}$ & $\begin{array}{l}30.6 \\
(2.2)\end{array}$ & $\begin{array}{l}18.7 \\
(2.5)\end{array}$ & $\begin{array}{l}11.7 \\
(1.8)\end{array}$ & $\begin{array}{r}7.3 \\
(3.3)\end{array}$ & 100 \\
\hline & $>30$ & $\begin{array}{r}5.4 \\
(0.4)\end{array}$ & $\begin{array}{l}57.2 \\
(4.9)\end{array}$ & $\begin{array}{l}21.9 \\
(1.5)\end{array}$ & $\begin{array}{l}11.3 \\
(2.0)\end{array}$ & $\begin{array}{r}9.6 \\
(2.2)\end{array}$ & 100 & $\begin{array}{l}34.4 \\
(2.7)\end{array}$ & $\begin{array}{l}29.7 \\
(2.3)\end{array}$ & $\begin{array}{l}17.6 \\
(1.3)\end{array}$ & $\begin{array}{l}10.2 \\
(1.1)\end{array}$ & $\begin{array}{r}8.0 \\
(3.5)\end{array}$ & 100 \\
\hline \multirow[t]{4}{*}{$\begin{array}{l}\text { Rural origin } \\
(28.9 \%)\end{array}$} & $<18$ & $\begin{array}{r}5.3 \\
(0.5)\end{array}$ & $\begin{array}{l}80.2 \\
(3.6)\end{array}$ & $\begin{array}{l}16.2 \\
(2.6)\end{array}$ & $\begin{array}{r}2.9 \\
(0.9)\end{array}$ & $\begin{array}{r}0.7 \\
(0.3)\end{array}$ & 100 & $\begin{array}{l}44.8 \\
(3.3)\end{array}$ & $\begin{array}{l}31.7 \\
(2.5)\end{array}$ & $\begin{array}{l}14.3 \\
(1.1)\end{array}$ & $\begin{array}{r}6.2 \\
(0.8)\end{array}$ & $\begin{array}{r}3.0 \\
(1.7)\end{array}$ & 100 \\
\hline & $19-24$ & $\begin{array}{r}7.1 \\
(0.6)\end{array}$ & $\begin{array}{l}78.2 \\
(4.8)\end{array}$ & $\begin{array}{l}17.0 \\
(3.4)\end{array}$ & $\begin{array}{r}3.8 \\
(1.1)\end{array}$ & $\begin{array}{r}1.0 \\
(0.4)\end{array}$ & 100 & $\begin{array}{l}47.4 \\
(3.7)\end{array}$ & $\begin{array}{l}31.6 \\
(2.4)\end{array}$ & $\begin{array}{l}13.8 \\
(1.2)\end{array}$ & $\begin{array}{r}4.7 \\
(0.9)\end{array}$ & $\begin{array}{r}2.5 \\
(1.0)\end{array}$ & 100 \\
\hline & $25-30$ & $\begin{array}{r}5.7 \\
(0.4)\end{array}$ & $\begin{array}{l}77.2 \\
(4.5)\end{array}$ & $\begin{array}{l}17.5 \\
(3.1)\end{array}$ & $\begin{array}{r}3.9 \\
(1.0)\end{array}$ & $\begin{array}{r}1.4 \\
(0.5)\end{array}$ & 100 & $\begin{array}{r}47.2 \\
(4.0)\end{array}$ & $\begin{array}{l}30.0 \\
(2.3)\end{array}$ & $\begin{array}{l}14.3 \\
(1.1)\end{array}$ & $\begin{array}{r}7.0 \\
(1.9)\end{array}$ & $\begin{array}{r}1.6 \\
(0.6)\end{array}$ & 100 \\
\hline & $>30$ & $\begin{array}{l}10.7 \\
(0.6)\end{array}$ & $\begin{array}{l}79.0 \\
(3.5)\end{array}$ & $\begin{array}{l}15.8 \\
(2.2)\end{array}$ & $\begin{array}{r}4.0 \\
(1.1)\end{array}$ & $\begin{array}{r}1.3 \\
(0.4)\end{array}$ & 100 & $\begin{array}{l}46.7 \\
(2.8)\end{array}$ & $\begin{array}{l}30.6 \\
(2.2)\end{array}$ & $\begin{array}{l}14.4 \\
(1.2)\end{array}$ & $\begin{array}{r}5.7 \\
(1.1)\end{array}$ & $\begin{array}{r}2.7 \\
(1.3) \\
\end{array}$ & 100 \\
\hline
\end{tabular}

Note: standard errors, in parentheses, account for the sample design. 
Migrant women of urban origin are the most mobile representing 41\%, 34\%, and $14 \%$ of women in large cities, urban and rural areas, respectively. Women of rural origin are less mobile than urban, except in rural-to-rural migration. These latter group of women represents $17 \%, 23 \%$, and $29 \%$ of the women across the three areas of residence. In addition, the distribution of women across age at migration generally follows a U-shaped pattern with the highest proportion of women migrating before adulthood and after age 30, potentially mothers and daughters (refer to column 1 in Table 3).

Differences across areas of residence in educational attainment and wealth profiles reveal structural disparities in access to formal education and basic services (refer to columns 2 to 10 in Table 3). Institutions granting medium and high-level degrees are concentrated in cities, and the provision of basic services is precarious in rural areas. For example, the proportion of women with more than 13 years of schooling is $25 \%$ in large cities, $18 \%$ in urban areas, and only $1 \%$ in rural. In terms of wealth, the percent of women in the $5^{\text {th }}$ quintile is $52 \%, 33 \%$, and $3 \%$ among women living in these three places, respectively.

Educational and wealth profiles of migrants vary substantially across origin, destination, and age at migration. These variations reflect how domestic migration involves processes of selection and limited improvement of socioeconomic conditions among migrants. By limited improvement I mean that despite migrants' positive selection, those moving from deprived rural to urban areas display worse educational and wealth profiles than non-migrant women at the destination. This pattern accentuates among women who migrate after age 25 .

This heterogeneity across destination, origin, and age at migration in migrants' socioeconomic conditions is likely to play a role in the way migration relates to family trajectories. It also casts 
doubt on the possibility to reconcile patterns by testing separate hypotheses on the role of selection, socialization, disruption, and adaptation mechanisms.

\section{Family formation and dissolution trajectories}

Figure 1 presents the 98 thousand individual family trajectories and the eight-category family typology separate by are of residence. The detailed results of the MCA and CA are reported in the appendix section "Identification and characteristics of the family typology".

Figure 1: Individual family trajectories, family typology and women's distribution by current area of residence
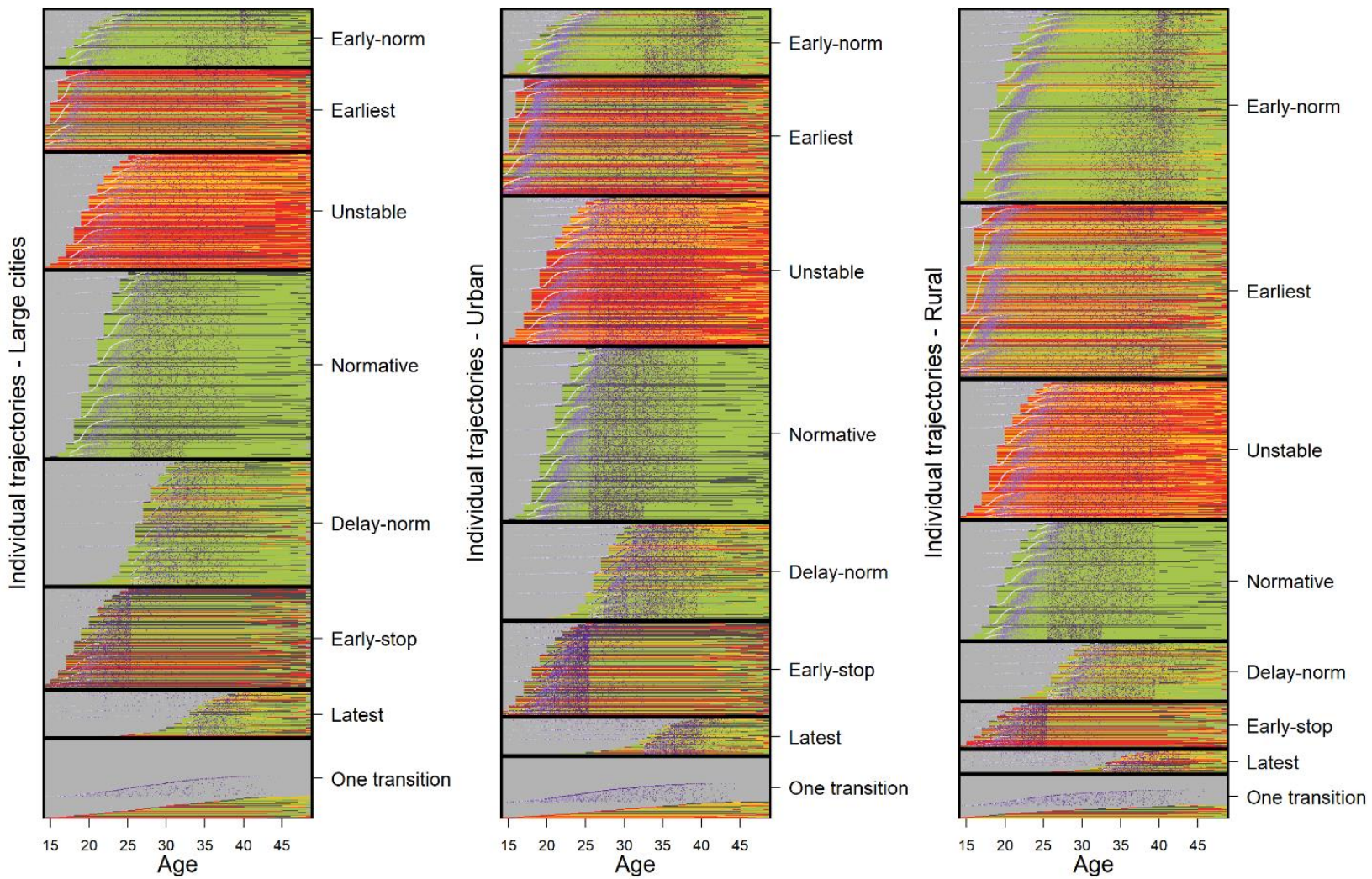

\section{Marital history}

Never married

Married Birth history

First Second $\bigcirc$ Last

Note: Individual trajectories are sorted by age at first marriage, children ever born and age at first birth within each family category. Interpretations should be cautious due to over plotting. 
Individual trajectories start at the age of 15 in the horizontal axis and are colored after the age at first marriage/union according to women's current and previous marital statuses. The trajectories of women who declared having only one partner are colored with a green (if currently Married) and yellow (if currently In union). These are women in life-long stable marriages and consensual unions. Because the timing of second and high-order marriages and unions cannot be identified in the DHS, women who reported more than one marriage or union are colored in red regardless of their current marital status. Similarly, women who were separated, divorced, or widow at the time of the survey are colored in grey (Unknown) because it is not possible to know when did the separation, divorce, or death of the partner occurred. Purple dots of varying shade represent the first, second, and last births.

To emphasize the distinctiveness of each category, I label them according to their most salient characteristic. These labels are arbitrary and incomplete because one word cannot fully account for all the characteristics of each category. Table A2 in the appendix complements Figure 2, presenting a detailed examination of the typology.

I start by describing the "Normative" category. The characteristics of this group, in particular, its relative size, reflect tacit societal norms regarding marriage and the timing of family formation in LACar (Fussell and Palloni, 2004; Quilodrán, 2008). The "Normative" category is the most prevalent, with $22 \%$ of the total women. On average, women in this category have 3.9 children, with $88 \%$ having at least three children. These births occur between ages 22 (first) and 31 (last). The "Normative" group also displays the highest prevalence of unique marriages. Virtually all women (99.8\%) reported having only one partner over their life course. There are no women in a consensual union in this group. 
This group is not majoritarian in rural areas; however, the group with the largest share of women in this area ("Early-norm") also displays a high prevalence of stable marriages (97\% women reported only one partner). This suggests that marital stability is also normative in rural areas. The use of the word 'normative' does not imply that this particular family path is more desirable than others in a moral sense. By using this word, I mean that these family trajectories are followed by a vast majority of women, thus reflecting an implicit societal norm. This societal norm is attached to the prevalence and influence of the catholic church (and other Christian institutions) in these countries, and the family values and beliefs associated with this religious affiliation (De Vos, 1995).

From bottom to top, the first family category comprises mainly women who did not have a child and did not enter marital/consensual unions, or only experienced one of these two transitions ("One transition"). ${ }^{2}$ Among the women who married (30\%) and gave birth (27\%) in this group, the mean ages at first marriage/union (29 years old) and birth (26 years old) are seven and three years higher than the overall average, respectively. The second category ("Latest") is the only group where, on average, the transition to childbearing and union formation co-occur, at about age 33; that is, ten years higher than the overall mean for both transitions. The average completed fertility in this group is relatively low, with 2.2 children per woman. Union stability is high, with $90 \%$ of the women reporting only one partner over their life course.

Women in the following group ("Early-stop") are very particular as they transition to family formation relatively early, on average, at ages 19 (marriage/union) and 20 (first birth) and have low complete fertility: 2.2 children. This configuration of features occurs because these women stop childbearing before age 24. Marital and union dissolution is very prevalent in this group of

\footnotetext{
2 See appendix for a detailed definition of this group.
} 
women, with $41 \%$ being divorced or separated at the time of the survey, and $26 \%$ reporting more than one partner over their life course.

Women in the following group ("Delay-norm") transition to union formation and first birth relatively late, at about ages 27 and 28, respectively. Women in this group have, on average, 2.8 children. Marital and union stability is high in this group, with $94 \%$ of the women reporting only one partner, and only $13 \%$ of them being divorced or separated by the time of the survey. Generally speaking, the four categories below the "Normative" category comprise family trajectories of low intensity, delayed transitions (except for "Early-stop") and, compressed family schedules, meaning that women in these groups form unions (through marriage or consensually) at late ages and have few children in a relatively brief period of their lives.

Early transitions to union formation and childbearing characterize the "Unstable" group. This group has the second largest percentage of divorced and separated women (19\%), and the largest percentage of women who had been in more than one marriage or union (59\%), meaning that $77 \%$ of these women experienced couple dissolution at some point in their lives. Interestingly, the average completed fertility of the "Unstable" group is higher than that of the "Normative" by almost one child (3.9 vs. 4.7$)$.

The following group includes mostly women who entered unions, on average, two to three years before the legal age of majority ("Earliest"). The transition to first birth occurs one year after union/marriage. This group displays the second highest complete fertility and intermediate levels of marriage prevalence, union stability, and re-partnering. The average completed fertility of this group is 7.3 children, the percentage married $43 \%$, the percentage separated or divorced $16 \%$, and the percentage reporting multiple partners $40 \%$. Finally, women in the last group ("Earlynorm") display early ages of transition to family formation, high prevalence of marriages (90\% 
of women are married), and low marital instability; only $2.6 \%$ reported to be divorced or separated, and less than $4 \%$ reported more than one partner. One distinctive characteristic of this last group is its extended period of childbearing. On average, women give birth to their last child at age 39 .

To summarize, the categories of the typology vary in two interrelated ways. First, they range from a category that groups mostly never married and childless women ("One transition") to a category that comprises mostly women who transitioned to union formation at an early age, had multiple partners, and high fertility ("Earliest"). I termed these two opposing family trajectories as low-intensity and high-intensity family paths, respectively. Second, family categories also vary in the prevalence of marriage, cohabitation, divorce, and separation. This variation allows for separating normative family paths: universal, unique, and stable marriages, from less normative ones: a dual regime of marriage and cohabitation, unstable unions, and multiple partners over the life course.

Some heterogeneity is not accounted for by this typology. Measured as the ratio of the withinclusters variance over the total variance, this proportion is 0.35 (refer to Figure A1, R2sq, continuous line). This result is analogous to an $\mathrm{R}^{2}$ of 0.65 in a regression framework, meaning that the grouping in Figure 2 accounts for a significant portion of the variability of the family trajectories. Beyond this technical criterion, these eight groups describe distinct fertility and partnership trajectories and their distribution across areas of residence and, over time (not shown), are consistent with the literature on family dynamics in LACar countries presented in the previous section. Together, the high percentage of explained variance and the historical consistency of the typology, suggest that the distribution of women in this typology is a valid object of study; I term this distribution family profile. 
How does this family profile look across migration streams (origin-destination), educational attainment levels (i.e., social class), and age at migration groups? Answering this question requires the comparison of 108 family profiles, i.e., comparing family profiles across three areas of residence, two origin areas, five age at migration groups, and four groups of educational attainment. Figures 2, 3, and 4 present the relational plots that allow us to compare these family profiles in large cities, urban areas, and rural areas, respectively. ${ }^{3}$

I focus on the first two PCA-axes as they comprised $84 \%$ of the total variance across family profiles; the percentages of the variance in the third to seventh axes are very low: $6 \%, 4 \%, 3 \%$, $2 \%$, and $2 \%$, respectively, thus unimportant.

Figures 2 to 4 can be interpreted jointly (i.e., superposed); however, I separate them by destination (figures) and origin (panels) to ease interpretation. In all three figures, the left panels include the family profiles of migrants of urban origin and the right panel those of migrants of rural origin. Family categories are displayed as "+" grey markers. Groups of women by age at migration and educational attainment are differentiated with four markers and five colors, respectively. The sizes of the markers are proportional to the percentage of women in the educational attainment group within the age at migration (as displayed in Table 3). Lines connect educational attainment groups to highlight patterns by social class in each age at migration group. The center of the plot represents the overall family profile, i.e., the marginal distribution of the family typology. In consequence, all the associations displayed in Figures 2 to 4 are relative to the overall distribution of the typology.

\footnotetext{
${ }^{3}$ Family profiles are reported in Table A4 for large cities, Table A5 for urban areas, and Table A6 for rural areas.
} 
Figure 2: Family profiles by origin, age at migration, and educational attainment in Large cities

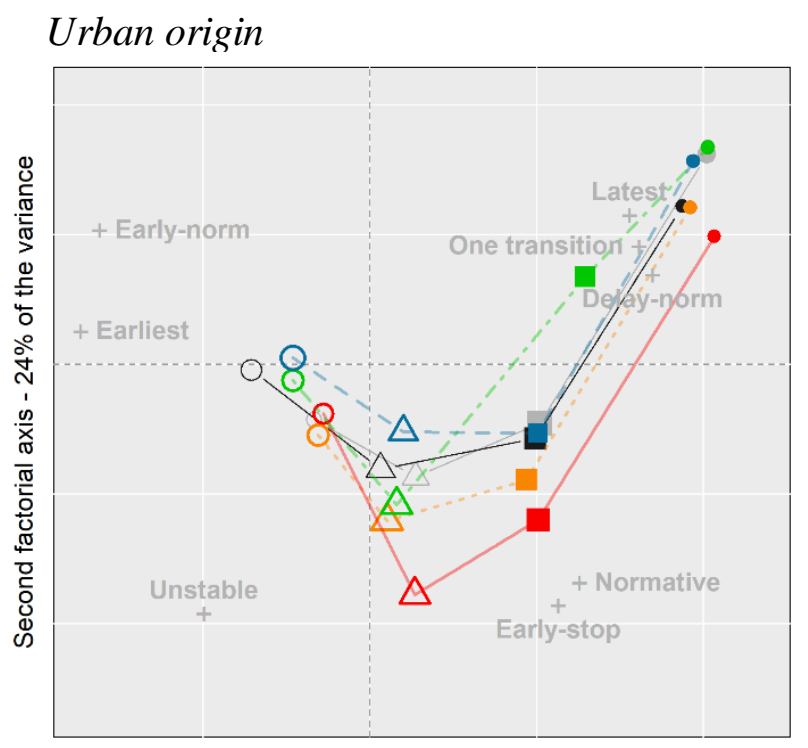

First factorial axis - $60 \%$ of the variance

Years of schooling

○ $0-4 \Delta 5-8$ - $9-12 \cdot 13+$

Age at migration

\section{Rural origin}

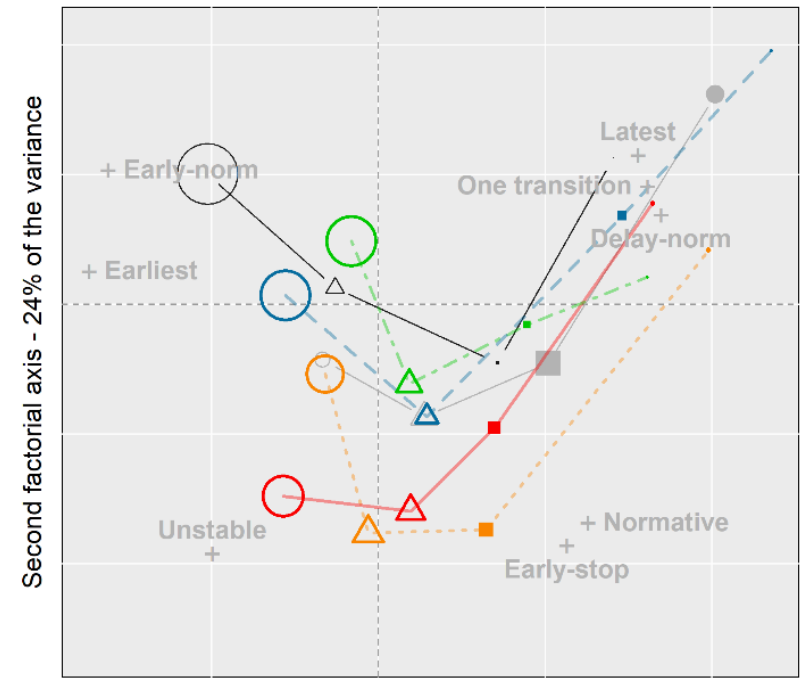

First factorial axis $-60 \%$ of the variance

Relative size

ه $25 \%$ D $50 \%$

$\begin{array}{llll}\text { Non-migrant at origin } & \ldots & \text { Before age } 18 \\ & \text { Non-migrant at destination } & 19-24\end{array}$

- - 25-30

- After age 30

Notes: The percentages of variance of the axes refer to the total variance across the 108 family profiles, i.e., to the total sum of squared Euclidean distances of the PCA-coordinates. There were no significance patterns along the third axis (6\% of the total variance).

I start with Large cities (Figure 2). The family profiles of non-migrant women in large cities are plotted in both panels using light-grey markers according to women's years of schooling. These markers are similar in size because women in large cities are almost uniformly distributed across the four categories of educational attainment, with a slight concentration in the group of 9 to 12 years of schooling (31.1\% of women, according to Table 3). A solid line connects these four markers, forming a U-shaped pattern that reflects the associations between educational attainment and family categories. Highly educated women are overrepresented in three family categories: "One transition," "Latest," and "Delay-norm," whereas the low-educated women 
are close, therefore overrepresented in the "Earliest" and "Earliest-norm" family paths. For example, the percentages of women in the "Latest" category from the lowest to the highest educational attainment group are 3.2\%, 3.3\%, 5.2\%, and $11.7 \%$ (overall percentage, $4.7 \%$ ). Likewise, the proportion of women in the "Earliest" category varies from $21.6 \%$ among the bottom educational attainment group to almost zero (1.8\%) among women at the top of the educational attainment categories (refer to Table A4).

In the left panel of Figure 2, the black markers and line, representing the family profiles of nonmigrant women in urban areas, overlap with those of non-migrant women in large cities. This overlap means that the relationship between educational attainment and the family categories holds for both groups (non-migrant women at origin and destination) and that the family profiles of women resemble each other in all educational attainment categories. There is virtually no difference in the distribution of women across family paths between stayers in large cities and urban areas. This result is likely to be driven by the fact that women of urban origin include both urban areas and large cities.

As for migrants of urban origin, the left panel shows that their family profiles replicate the educational disparities observed among non-migrant (U-shape). These repeated U-shape patterns mean that urban-to-large-cities migration is not associated with substantial disruptions in family profiles. The only slight exception concerns women of low educational attainment who migrated between ages 19 and 24. Among these group of young-adult migrants, the percentage of women in the "Unstable" (18.7\%) and "Normative" (30\%) categories are higher than among their nonmigrant counterparts of the same educational attainment (16.2\% and $23.7 \%$, respectively). Indeed, low educated young-adult migrants of urban origin in large cities display the second 
largest proportion in the "Normative" category, only surpassed by highly educated women of rural origin, where $48.3 \%$ of women followed the "Normative" path.

In contrast to the overlapping pattern in the left panel, the right panel displays a non-concurrent distribution of family profiles for migrant women of rural origin, signaling the multiplicity of adaptations of rural family profiles to large cities' context. This lack of overlapping patterns is especially visible for women in the lowest and low educational attainment categories, the two largest groups as reflected by the markers' sizes. Women in these two groups who migrated from rural areas to large cities are less likely to be in the "Earliest" and "Early-norm" categories compared to those who stayed in rural areas. Therefore, migrant women of rural origin are more likely to be in the "Unstable," "Early-stop," and "Normative" categories than non-migrant, meaning that rural-to-large-cities migration is associated, simultaneously, with lower fertility, higher marriage/union instability, and early stopping of childbearing. This association is especially strong for young (0 to 18) and young-adult (19 to 24) migrant women with 0 to 4 and 5 to 8 years of schooling.

Notably, educational differences remain across all age at migration groups, meaning that domestic migration does not erase the role of educational attainment in differentiating women's family profiles. For example, women who migrated after age 30 and completed 13 years of schooling (top-right most point in the right panel) display a very different family profile compared to lowest and low educated women who migrated at the same age (second quadrant). These latter two groups of women display family profiles that resemble the family profile of uneducated women at destination (refer to Table A4). It is important to recall that the patterns observed for lowest and low educated women are more critical than those observed among 
highly educated migrants given the differences in the size of these three groups $(62.5 \%$ lowest, $21.1 \%$ low, $12.0 \%$ high, and $4.4 \%$ highest, as per Table 3 ).

In the left panel of Figure 3, family profiles' distribution of urban-to-urban migrant women overlaps with the family profile of non-migrant, meaning that this type of migration is not associated with substantial disruptions in family profiles. Non-migrant and migrant women (with urban residential background) in urban areas have very similar family profiles at all educational attainment levels. As in large cities, the only exception concerns women who migrated as young adults (19 to 24). Educational differences are diminished in this group, and women are more likely to be in the "Unstable" category if they are low educated, and in the "Early-stop" and "Normative" categories if they completed more than nine years of schooling. For example, the proportion of women in the "Unstable" category is $23.7 \%$ among uneducated ( 0 to 4 years of schooling) young-adult migrants, and $17.7 \%$ among their non-migrant counterparts. At the other end of the educational categories, the proportion of women in the "Normative" category is $36.4 \%$ among young adult migrants with more than 13 years of schooling; this figure is $22.3 \%$ among their non-migrant educational counterparts (refer to Table A5). These patterns confirm the higher propensity of young-adult urban migrants to follow family trajectories of intermediate fertility levels (not necessarily low fertility), intermediate timing of the transition to union formation and childbearing, and unique and stable marriages.

For women of rural origin, migration to urban areas is associated with a reduction in the proportion of women in the "Earliest" and "Early-norm" categories. The family profiles of rural migrants appear closer to the family profiles of urban non-migrant than the family profiles of rural stayers, which signal adaptation. This adaptation to more urban-like family profiles concerns mainly the groups of low educational attainment, and it is less significant than the one 
observed in Figure 3 for large cities, meaning that both the context of reception and migrants' background matter for how migration associates with family formation paths. As for large cities, the age group that displays the most significant disruptions is that of young-adult migrants (19 to 24) for whom family profiles are significantly displaced towards the bottom area of the plot.

Figure 3: Family profiles by origin, age at migration, and educational attainment in Urban areas

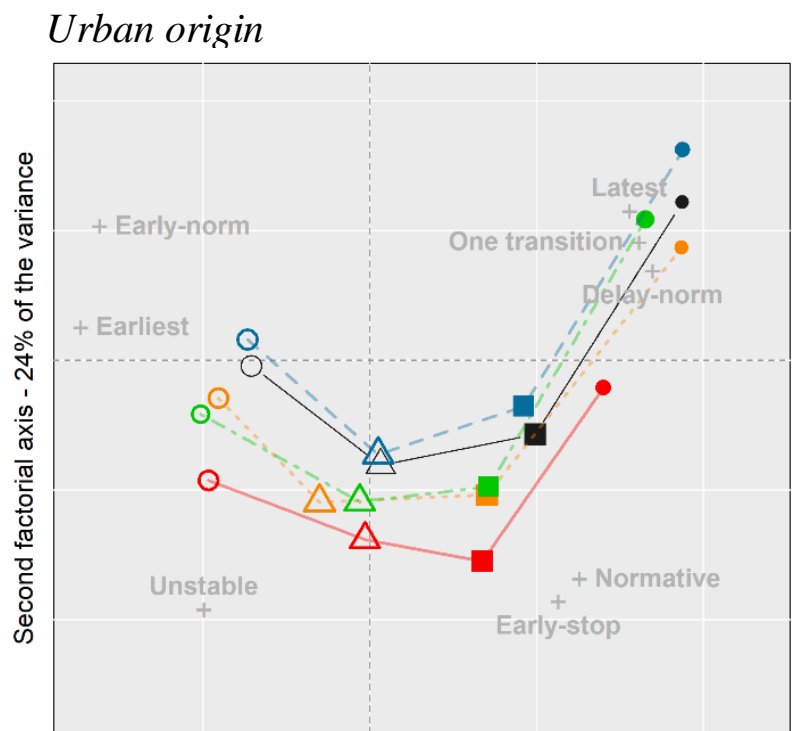

First factorial axis - $60 \%$ of the variance

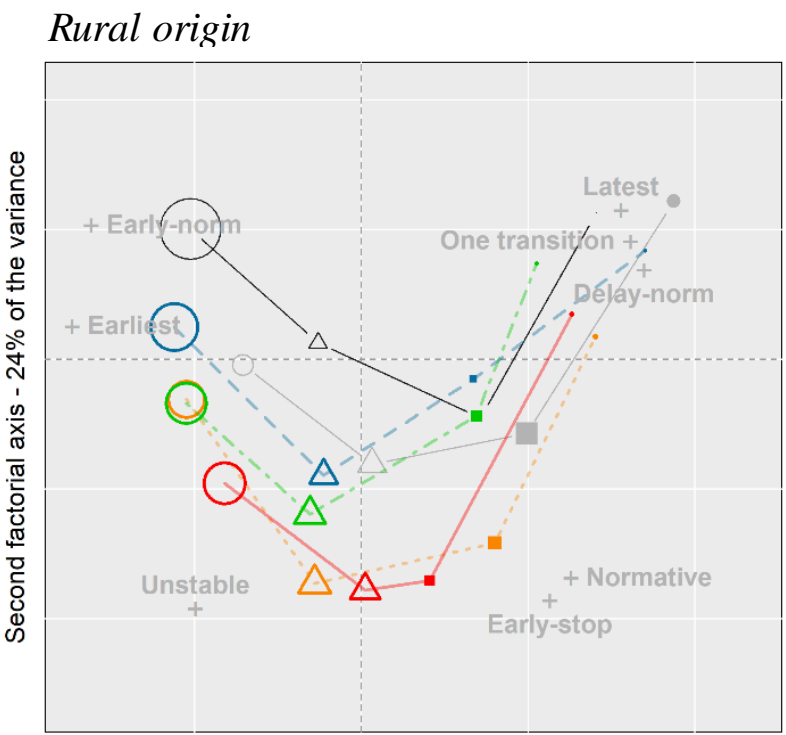

First factorial axis - $60 \%$ of the variance

Relative size

25\% Q $50 \%$ D5\%

Age at migration

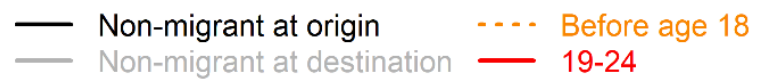

- $25-30$

- After age 30

Notes: The percentages of variance of the axes refer to the total variance across the 108 family profiles, i.e., to the total sum of squared Euclidean distances of the PCA-coordinates. There were no significance patterns along the third axis (6\% of the total variance).

Educational differences in family profiles remain as all the lines representing migrant women are U-shaped, having low-educated and highly educated women in the two extremes. Together, these patterns mean that migration from rural to urban areas is associated with the "Unstable," 
"Early-stop," and "Normative" family pathways, while weakly attached to the degree of intensity of family trajectories. This latter aspect (intensity) maps on more tightly to women's educational attainment.

Figure 4 focuses on rural areas as a destination. The majority of migrants in rural areas are low educated women, and their family profiles resemble those of non-educated rural stayers; most women follow the "Early-norm" and "Earliest" categories. Also, migration to rural areas displays two main patterns related to early and late migration. For women who migrated before age 25, family profiles move sharply towards the left of the panels (partially disrupting the Ushaped pattern), meaning that early migration to rural areas and high educational attainment are not associated with the family categories of delayed transitions to family formation and low fertility. This result should not be overemphasized because it refers to a tiny proportion of women.

As for migration after age 25, family profiles' distribution replicates the educational discrepancies of urban non-migrants (left panel), and rural non-migrants (right panel), meaning that women who migrated as adults to rural areas have similar family profiles compared to rural non-migrants. The similarity is apparent between rural migrants and rural stayers. These patterns are consistent with the idea that late migration between similar contexts should be associated with less family disruption; the extent to which this may be driven by return migration is unknown. In other words, when migration takes place later in life (or as a return) and across similar contexts (rural to rural), family paths are not expected to be disturbed. 
Figure 4: Family profiles by origin, age at migration, and educational attainment in Rural areas

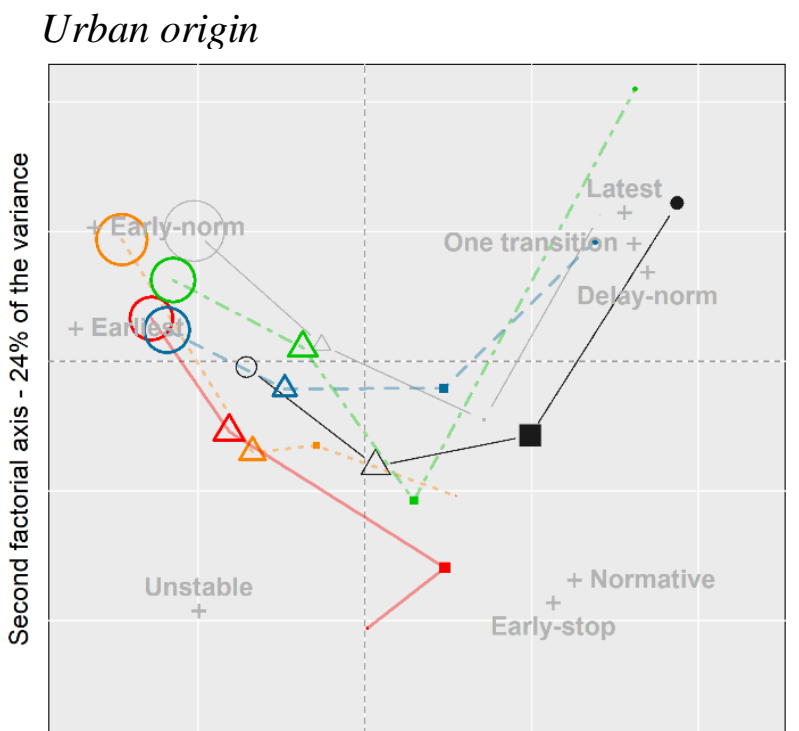

First factorial axis $-60 \%$ of the variance

\section{Rural origin}

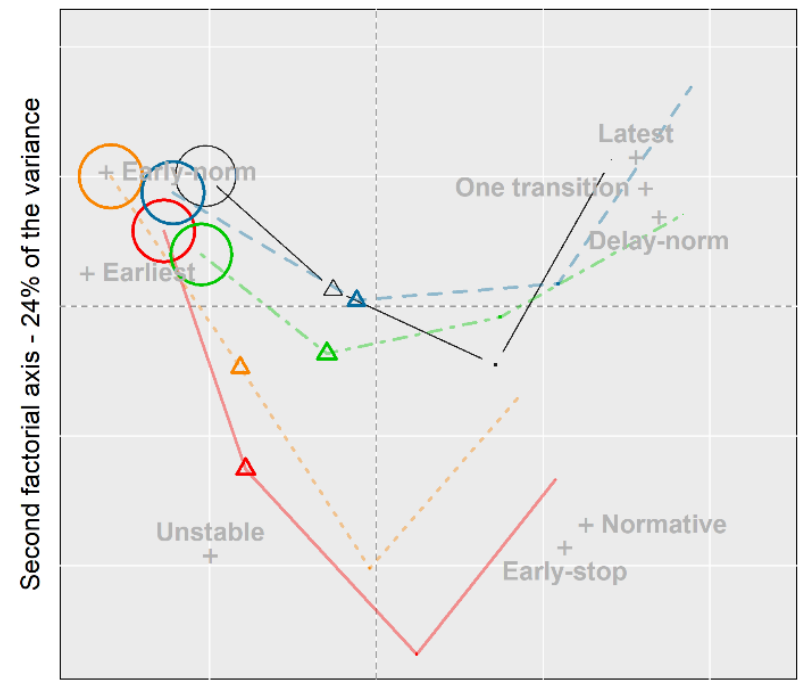

First factorial axis $-60 \%$ of the variance

Relative size

- $25 \%$ D $50 \%$
Years of schooling

$\circ 0-4 \triangle 5-8 \quad \cdot 9-12 \cdot 13+$

Age at migration

- Non-migrant at origin … Before age 18

- Non-migrant at destination — 19-24
- - $25-30$

- After age 30

Notes: The percentages of variance of the axes refer to the total variance across the 108 family profiles, i.e., to the total sum of squared Euclidean distances of the PCA-coordinates. There were no significance patterns along the third axis (6\% of the total variance).

\section{Conclusions and discussion}

This paper analyzes how internal migration and family trajectories relate to one another using a life course processual approach. A data-driven eight-category typology describes the distinct family paths followed by women born between 1937 and 1973 in 10 LACar countries. Two hierarchically related constructs separate the eight family categories of this typology. The first construct separates family paths according to the number and concentration of family events over the life course. There is a group of family categories of low-intensity and delayed (or compressed) family formation trajectories. And, there is a group of family categories of high- 
intensity and early-transition paths. The second construct relates to the prevalence of formal marriage and marriage stability. This construct separates normative and non-normative family trajectory categories. Women's socioeconomic status is strongly correlated with the first construct (intensity), whereas the second (normative) one relates more to women's migration status in ways that vary according to their age at migration, origin, and destination.

I study these associations through family profiles, i.e., the conditional distribution of women across the eight family categories of the family typology by age at migration and educational attainment. Differences across these family profiles reflect the structural and socially stratified nature of family paths as well as their associations with migration. These results underline the fact that it is among vulnerable individuals that family profiles are more disrupted by migration compared to individuals in socially privileged positions. Vulnerability is understood here in terms of low socioeconomic status and the conflicting confluence of migration and other transition to adulthood processes (school termination, job market insertion, leaving the parental home, among others). To the extent that both, family formation and migration, require resources (time, money, social support, to mention a few), their temporal coincidence may be more demanding for low-educated women than highly educated. Indeed, high socioeconomic status and late migration are both associated with minimal disruption in family profiles.

Moreover, these results suggest that the so-called disruptions associated with the migration experience, do not necessarily mean deviations from the norm. Indeed, migrant women are more likely to follow normative family paths, as well as family paths of unstable marriage and unions, and early stop of childbearing, compared to non-migrant. In other words, internal migration is such a constituent part of LACar's demographic history that the family trajectories of migrants contribute significantly to the tacit societal norms underlying family trajectories in the region. 
This result is in sharp contrast with the prevailing conception of migrants as having very distinct and non-normative (unusual) preferences/behaviors. The fact that this conclusion concerns lowclass women primarily suggests that further attention should be devoted to understanding the drivers of family and fertility change among less privileged groups (e.g., low-educated young migrant women in cities), who tend to be underrepresented in mainstream theories of demographic change (van de Kaa, 1996; Mason, 1997). This particular attention to disadvantaged groups is essential for understanding demographic and social change in LACar societies and potentially other low- and middle-income countries in Africa and Asia, given the high and sustained levels of social and economic inequality.

Differences in the social and economic opportunity structures across large cities, urban areas, and rural areas allow me to speculate about the potential mechanisms driving the heterogeneity in family profiles. Because living in large cities imposes material restrictions to family expansion and stability, the similarity in family outcomes between migrant and non-migrant groups can be interpreted as a structural adaptation. This structural assimilation stems from the material constraints that a large city imposes on migrant women. These include higher childbearing and childrearing costs, separation from support networks of family members left behind, and low income in a predominantly monetary economy. This latter aspect likely undermines the economic prospects of the low-educated who come into cities from rural areas. Hence, stopping childbearing shortly after the first birth, limiting fertility, being part of a stable formal marriage, or having multiple partners over the life course, become features of the family paths among migrants in large cities. That this association is stronger among more vulnerable groups, i.e., low-educated women of rural origin who migrated as young adults makes the constraint-oriented interpretation plausible. 
The prevalence of live-in arrangements among female domestic workers in LACar cities, along with the overrepresentation of rural-to-urban migrants in this occupation, underline the importance of material and financial constraints for family formation paths (Jelin, 1977; Moya, 2007). Further research on the family formation trajectories of domestic workers would further illuminate the contribution of this group to family change and fertility decline in LACar.

Other urban areas represent an intermediate context between the economic and financial demands of large cities and the more flexible conditions, economically speaking, that characterize rural settings. For that reason, only women who migrated to urban areas between ages 19 to 24 display disruptions in their family profiles, compared to those who did not migrate. These disruptions depend on their socioeconomic status. Among this age-at-migration group, the association between migration and family means relatively delayed-unstable family paths for lower-educated women and relatively stable-normative family trajectories for the highly educated. Among women of rural origin, the displacement of family profiles towards the "Unstable" and "Normative" family categories is apparent and it is more robust for those who migrated before age 24. Despite the lower prevalence of domestic work in urban areas compared to cities, these latter results may also concern domestic workers in live-in or live-out arrangements.

In rural areas, it is among women who migrated before and during crucial ages for family formation that family profiles depict the most considerable deviations compared to family profiles of women at the origin. The fact that these deviations are more significant among the highly educated than the less educated highlights the importance of the context of reception for family trajectories. Despite the fact of being highly educated, young-adult-migrant women in rural areas are underrepresented in low-intensity, delayed transition, and no-transition family 
categories. On the contrary, for women who migrated after age 25 and 30, family profiles tend to replicate the educational differences of women at the destination. This result could be interpreted in terms of selection, and the extent to which it is driven by return migration remains unanswered.

Internal migration in LACar countries involved the mobility of many women with diverse educational and wealth profiles across very distinct contexts and, possibly, for a very diverse set of reasons from voluntary to forced displacement. This diversity produces heterogeneous patterns in the relationship between family and migration that have not been jointly studied before. Hypothesis-based approaches have been incapable of accounting for this heterogeneity as most of these patterns become invisible when analyses focus on measuring the degree of selection, assimilation, adaptation, or socialization, separately, without accounting for the socially stratified nature of family dynamics. For all these patterns exist within concrete stratification systems, the interpretation of these separate explanations as complementary is doubtful.

What seems to be at a higher level of generality is that all these mechanisms contributed to fertility and family change in the region while always remaining subordinate to the socially stratified nature of the family. Results in this paper show that migration and family formation processes are embedded in the social structure in several ways. First, because migration and family formation require resources, the relationship between two processes depends on the social and economic background of women; low class and high-class women experience this confluence differently. Second, only when socioeconomic opportunities at origin and destination are similar for a given group of migrants, migration is non-disruptive for family trajectories. Third, both socialization and assimilation/adaptation mechanisms seem to be at play; the latter 
mechanisms are especially notable among low-class women, which makes this group of women a significant contributor to family change during this period. 


\section{References}

Alvarado, S. E. and Massey, D. (2010) 'In Search of Peace: Structural Adjustment, Violence, and International Migration', The Annals of the American Academy of Political and Social Science, 630(1), pp. 137-161. doi: 10.1002/ana.22528.Toll- like.

Arnaut, J. (2010) 'Understanding the Latin American Gap during the era of Import Substitution', in Southern Hemisphere Economic History Summer School. Montevideo, Uruguay: Universidad de la Republica de Uruguay, pp. 1-24.

Arriagada, I. (2007) 'Familias latinoamericanas: cambiantes, diversas y desiguales', Papeles de Población, (53), pp. 9-22. doi: 1405-7425.

Babb, S. (2005) 'THE SOCIAL CONSEQUENCES OF STRUCTURAL ADJUSTMENT : Recent Evidence and Current Debates', Annual Review of Sociology, 31, pp. 199-222. doi: 10.1146/annurev.soc.31.041304.122258.

Baer, W. (1972) 'Import Substitution and Industrialization in Latin America: Experiences and Interpretations', Latin American Research Review, 7(1), pp. 95-122.

Bernard, A. et al. (2017) 'Comparing internal migration across the countries of Latin America: A multidimensional approach', PLoS ONE, 12(3), pp. 1-24. doi: 10.1371/journal.pone.0173895.

Bethell, L. (1998) 'Latin America: Economy and Society Since 1930', in The Cambridge History of Latin America. 1st edn. Oxford: Oxford University Press. doi: 10.1017/CBO9781107415324.004.

Billari, F. C. (2001) 'Sequence Analys is in Demographic Research', Canadian Studies in Population, 28(2), pp. 439-458. doi: 10.3200/JECE.36.4.332-344.

Brea, J. (2003) 'Population Dynamics in Latin America', Population Bulletin, 58(1), pp. 3-36.

Brockerhoff, M. and Yang, X. (1994) 'Impact of migration on fertility in sub-Saharan Africa', Biodemography and Social Biology, 41(1-2), pp. 19-43. doi: 10.1080/19485565.1994.9988857.

Cornwell, B. (2015) Social Sequence Analysis. 1st edn. Cambridge: Cambridge University Press. doi: $10.1017 / \mathrm{CBO} 9781316212530$.

Davis, K. and Casis, A. (1946) 'Urbanization in Latin America', The Milbank Memorial Fund Quarterly, 24(2), pp. 186-207.

Ducoff, L. et al. (1965) 'The Role of Migration in the Demographic Development of Latin America', The Milbank Memorial Fund Quarterly, 43(4), pp. 197-216.

Dufour, D. L. and Piperata, B. A. (2004) 'Rural-to-urban migration in Latin America: An update and thoughts on the model', American Journal of Human Biology, 16(4), pp. 395-404. doi: 10.1002/ajhb.20043.

Dyson, T. (2011) 'The Role of the Demographic Transition in the Process of Urbanization', Population and Development Review, 37(Demographic Transition and Its Consequences), pp. 34-54.

Ebank, E. (1993) Determinantes Socioeconomicos de la migracion interna. Santiago de Chile: 
Comisión Económica para América Latina y el Caribe.

Elizaga, J. C., Lee, E. S. and Arias, J. (1965) 'Internal Migrations in Latin America', The Milbank Memorial Fund Quarterly, 43(4), pp. 144-165.

Eryurt, M. A. and KOÇ, İ. (2012) 'Internal Migration and Fertility in Turkey: Kaplan-Meier Survival Analysis', International Journal of Population Research, 2012, pp. 1-11. doi: 10.1155/2012/329050.

Esteve, A. and Florez-Paredes, E. (2014) 'Edad a la primera unión y al primer hijo en América Latina: estabilidad en cohortes más educadas', Notas de Población, (99), pp. 39-65.

Esteve, A. and Lesthaeghe, R. J. (2016) Cohabitation and Marriage in the Americas: Geohistorical Legacies and New Trends. Edited by A. Esteve and R. J. Lesthaeghe. Cham: Springer International Publishing. doi: 10.1007/978-3-319-31442-6.

Fussell, E. and Palloni, A. (2004) 'Persistent Marriage Regimes in Changing Times', Journal of Marriage and Family, 66(5), pp. 1201-1213.

Goldberg, D. (1959) 'The Fertility of Two-Generation Urbanites', Population Studies, 12(3), pp. 214-222.

Goldstein, S. (1973) 'Interrelations Between Migration and Fertility in Thailand', Demography, 10(2), pp. 255-241.

Goldstein, S. and Goldstein, A. (1981) 'The Impact of Migration on Fertility : an "Own Children" Analysis for Thailand', Population Studies, 35(2), pp. 265-284.

Greenacre, M. and Blasius, J/ (2006) 'The Geometric Analysis of Structured Individuals x Variables Tables', in Greenacre, Michel and Blasius, Jörg (eds) Correspondence Analysis and Related Methods. 1st edn. Boca Raton FL: Chapman \& Hall/CRC, pp. 137-160.

Guzmán, J. et al. (2006) 'The Demography of Latin America and the Caribbean since 1950', Population-E, 61(5-6), pp. 519-576. doi: 10.3917/pope.605.0519.

Hervitz, H. M. (1985) 'Selectivity, Adaptation, or Disruption? A Comparison of Alternative Hypotheses on the Effects of Migration on Fertility: the Case of Brazil.', The International migration review, 19(2), pp. 293-317. doi: 10.2307/2545774.

Hoffman, K. and Centeno, M. A. (2003) 'The Lopsided Continent: Inequality in Latin America', Annual Review of Sociology, 29. doi: 10.1146/annurev.soc.29.010202.100141.

Jelin, E. (1977) 'Migration and Labor Force Participation of Latin American Women: The Domestic Servants in the Cities', Signs, 3(1), pp. 129-141. doi: 10.1086/493446.

Jensen, E. R. and Ahlburg, D. A. (2004) 'Why does migration decrease fertility? Evidence from the Philippines', Population Studies, 58(2), pp. 219-231. doi: 10.1080/0032472042000213686.

van de Kaa, D. J. (1996) 'Anchored Narratives: The Story and Findings of Half a Century of Research into the Determinants of Fertility', Population Studies, 50(3), pp. 389-432.

Kulu, H. (2005) 'Migration and Fertility: Competing Hypotheses Re-Examined', European Journal of Population, 21(1), pp. 51-87. doi: 10.1007/s10680-005-3581-8. 
Lebart, L., Morineau, A. and Piron, M. (1997) Statistique Exploratoire Multidimensionnelle. 2nd edn. Paris: Dunod.

Lee, B. S. (1992) 'The Influence of Rural-Urban Migration on Migrant' s Fertility Behavior in Cameroon', International Migration Review, 26(4), pp. 1416-1447.

Lindstrom, D. P. (2003) 'Rural-urban migration and reproductive behavior in Guatemala', Population Research and Policy Review, 22, pp. 351-372.

Lindstrom, D. P. and Hernández, C. H. (2006) 'Internal Migration and Contraceptive Knowledge and Use in Guatemala', International Family Planning Perspectives, 32(03), pp. 146-153. doi: $10.1363 / 3214606$.

Macisco, J. and Myers, G. (1975) 'Introduction: Migration and Fertility', The International Migration Review, 9(2), pp. 111-114.

Macmillan, R. and Copher, R. (2005) 'Families in the Life Course: Interdependency of Roles, Role Configurations and Pathways', Journal of Marriage and Family, 67, pp. 858-879. doi: 10.1002/jctb.1957.

Martine, G. (1975) 'Migrant Fertility Adjustment and Urban Growth in Latin America', International Migration Review, 9(2), p. 179. doi: 10.2307/3002748.

Mason, K. (1997) 'Explaining fertility transitions', Demography, 34(4), pp. 443-454.

Montgomery, M. et al. (2003) Cities Transformed. Washington, D.C.: National Academies Press. doi: 10.17226/10693.

Moya, J. C. (2007) 'Domestic service in a global perspective: Gender, migration, and ethnic niches', Journal of Ethnic and Migration Studies, 33(4), pp. 559-579. doi: $10.1080 / 13691830701265420$.

Pantelides, E. A. (2004) 'Aspectos sociales del embarazo y la fecundidad adolescente en América Latina', Notas de población, (78), pp. 7-34.

Pardo, C. E. and Del Campo, P. C. (2007) 'Combinación de métodos factoriales y de anális is de conglomerados en R: El paquete FactoClass', Revista Colombiana de Estadistica, 30(2), pp. 231-245.

Portes, A. (2010) 'Migration and social change: Some conceptual reflections', Journal of Ethnic and Migration Studies, 36(10), pp. 1537-1563. doi: 10.1080/1369183X.2010.489370.

Preston, S. H. (1979) 'Urban Growth in Developing Countries: A Demographic Reappraisal', Population and Development Review, 5(2), pp. 195-215.

Quilodrán, J. (2008) ‘Un modelo de nupcialidad postransicional en América Latina?’, in III Congreso de la Asociación Latinoamericana de Población. Cordoba, Argentina, pp. 11-34.

Rodríguez Vignoli, J. (2010) La reproducción en la adolescencia y sus desigualdades en América Latina. Santiago de Chile: Comision de Poblacion y Desarrollo - CLACSO.

Rodríguez Vignoli, J. and Busso, G. (2009) Migración interna y desarrollo en América Latina entre 1980 y 2005. 1st edn. Santiago de Chile: Comisión Económica para América Latina y el 
Caribe.

Sassen-Koob, S. (1984) 'Notes on the Incorporation of Third World Women into Wage-Labor Through Immigration and Off-Shore Production', The International Migration Review, 18(4), pp. 1144-1167.

Torche, F. (2014) 'Intergenerational Mobility and Inequality: The Latin American Case', Annual Review of Sociology, 40(1), pp. 619-642. doi: 10.1146/annurev-soc-071811-145521.

United Nations (2018) World Urbanization Prospects The 2018 Revision. New York.

De Vos, S. (1995) Household Composition in Latin America. 1st edn. New York: Plenum Press.

Zárate, A. and Unger De Zárate, A. (1975) 'On the Reconciliation of Research Findings of Migrant-Nonmigrant Fertility Differentials in Urban Areas', International Migration Review, 9(2), pp. 115-156. doi: 10.2307/3002746. 


\section{Appendix}

Sample composition by birth cohort

Table A1 displays the number of women by birth cohort groups. The results reported in the paper correspond to the full sample. As a robustness check, I replicate the analysis for women who were born between 1945 and 1965. According to Table A2, this subsample offers a more homogeneous group of women that includes all countries. Figures A2, A3, and A4 displays the summary results for large cities, urban areas, and rural areas, respectively.

Table A1. Sample size by country and birth cohort group

\begin{tabular}{lrrrr}
\hline \multirow{2}{*}{ Country } & \multicolumn{3}{c}{ Birth cohort } & \multirow{2}{*}{ Total } \\
\cline { 2 - 4 } & {$[1935,1945)$} & {$[1945,1966)$} & {$[1966,1975]$} & \\
\hline Bolivia & 660 & 6,936 & 1,473 & 9,069 \\
Brazil & 604 & 4,398 & - & 5,002 \\
Colombia & 1,049 & 10,655 & 608 & 12,312 \\
Dominican Republic & 1,084 & 8,496 & - & 9,580 \\
Guatemala & 117 & 510 & - & 627 \\
Haiti & - & 3,093 & - & 3,093 \\
Mexico & 997 & 698 & - & 1,695 \\
Nicaragua & - & 5,003 & - & 5,003 \\
Paraguay & 324 & 824 & - & 1,148 \\
Peru & 1,133 & 31,192 & 18,191 & 50,516 \\
\hline Total & 5,968 & 71,805 & 20,272 & 98,045 \\
\hline
\end{tabular}

Note: The analytical sample includes women age 39 to 49 who were interviewed by the Demographic and Health Surveys from 1986 to 2012, i.e., the 1937 to 1973 birth cohorts. 


\section{Identification and characteristics of the family typology}

I use a two-step approach to develop the family typology in Figure 2. First, I conduct a Multiple Correspondence Analysis (MCA) on six categorical variables that measure women's family formation and dissolution trajectories. I kept all factorial dimensions with above-average contributions to the total explained variance (relative contribution > 5.8\%). Table A2 displays the percentage distribution of women across the six variables related to their family formation and dissolution trajectories.

Second, I use the retained factorial dimensions (six in these case, see left panel in Figure A1) to compute a pair-wise dissimilarity matrix. I use this matrix to cluster women into family trajectory categories according to their similarity. I implement the Ward method, followed by the $\mathrm{K}$-mean algorithm to identify the clusters.

Figure A1 summarizes the results of the MCA and CA. The left panel displays the 17 eigenvalues of the MCA and the proportion of the total variance that is accounted for by the first six $($ sum $=54 \%)$. The corrected proportion of explained variance using Greenacre and Blasius' (2006) correction formulae for $\mathrm{MCA}$ is $70 \%$, meaning that the first six factorial dimensions account for $70 \%$ of the total variation across the six active variables of the MCA. This high percentage of explained variance and the flat pattern in the contribution to the variance of the higher order eigen values, suggest that the first six factorial axes provide a good summary of the data, i.e., a good summary of women's family formation trajectories.

The right panel of Figure A1 displays the assessment of cluster solutions from 2 to 15 clusters, based on six standardized goodness of fit indicators. The peak in a solution of seven clusters across all positive non-monotonic indicators suggest that a seven-cluster solution is adequate. This decision is consistent with the relatively flat trend in all the monotonic indicators in clusters solutions with more than seven groups. These relatively flat trends indicate that the inclusion of an additional group, does not improve significantly the goodness of fit of the clustering. 
Table A2. Percentage distribution related to family trajectories by country

\begin{tabular}{|c|c|c|c|c|c|c|c|c|c|c|}
\hline \multirow{2}{*}{$\begin{array}{c}\text { Variables and } \\
\text { categories } \\
\end{array}$} & \multicolumn{10}{|c|}{ Country } \\
\hline & BOL & BRA & COL & DOM & GTM & HTI & MEX & NIC & PYR & PER \\
\hline & \multicolumn{10}{|c|}{$\begin{array}{l}\text { Percentage distribution } \\
\end{array}$} \\
\hline \multicolumn{11}{|c|}{ Age at first marriage or union } \\
\hline Never married & 4 & 6 & 9 & 2 & 3 & 2 & 5 & 3 & 6 & 7 \\
\hline Non-adult & 25 & 23 & 23 & 44 & 41 & 24 & 35 & 48 & 23 & 24 \\
\hline Adult-early & 55 & 55 & 49 & 44 & 47 & 56 & 47 & 43 & 53 & 50 \\
\hline Adult-mid & 12 & 12 & 13 & 9 & 8 & 14 & 11 & 5 & 14 & 14 \\
\hline \multirow{2}{*}{ Adult-late } & 4 & 4 & 5 & 2 & 1 & 3 & 3 & 1 & 4 & 4 \\
\hline & 100 & 100 & 100 & 100 & 100 & 100 & 100 & 100 & 100 & 100 \\
\hline \multicolumn{11}{|l|}{ Age at first birth } \\
\hline Childless & 4 & 8 & 8 & 4 & 4 & 5 & 7 & 3 & 6 & 6 \\
\hline Non-adult & 14 & 9 & 12 & 21 & 22 & 13 & 19 & 27 & 11 & 13 \\
\hline Adult-early & 63 & 60 & 58 & 59 & 59 & 59 & 58 & 58 & 61 & 59 \\
\hline Adult-mid & 15 & 18 & 17 & 13 & 13 & 19 & 14 & 10 & 17 & 17 \\
\hline \multirow[t]{2}{*}{ Adult-late } & 4 & 5 & 5 & 3 & 1 & 4 & 2 & 2 & 5 & 5 \\
\hline & 100 & 100 & 100 & 100 & 100 & 100 & 100 & 100 & 100 & 100 \\
\hline \multicolumn{11}{|l|}{ Age at last birth } \\
\hline Childless & 4 & 8 & 8 & 4 & 4 & 5 & 7 & 3 & 6 & 6 \\
\hline Adult-early & 7 & 11 & 16 & 19 & 7 & 8 & 6 & 11 & 9 & 10 \\
\hline Adult-mid & 25 & 35 & 37 & 41 & 21 & 19 & 27 & 36 & 20 & 32 \\
\hline Adult-late & 44 & 36 & 32 & 29 & 52 & 43 & 46 & 37 & 41 & 40 \\
\hline \multirow[t]{2}{*}{ Adult-latest } & 20 & 9 & 7 & 6 & 16 & 25 & 15 & 12 & 25 & 13 \\
\hline & 100 & 100 & 100 & 100 & 100 & 100 & 100 & 100 & 100 & 100 \\
\hline \multicolumn{11}{|l|}{ Children ever born } \\
\hline Childless & 4 & 8 & 8 & 4 & 4 & 5 & 7 & 3 & 6 & 6 \\
\hline One & 6 & 7 & 11 & 7 & 3 & 7 & 5 & 5 & 8 & 9 \\
\hline Two & 10 & 16 & 22 & 13 & 7 & 9 & 8 & 10 & 13 & 18 \\
\hline Three to four & 28 & 32 & 36 & 38 & 21 & 21 & 20 & 27 & 24 & 33 \\
\hline Five to six & 21 & 15 & 13 & 20 & 27 & 21 & 20 & 22 & 17 & 18 \\
\hline \multirow[t]{2}{*}{ Seven or more } & 31 & 21 & 10 & 18 & 39 & 38 & 41 & 33 & 32 & 16 \\
\hline & 100 & 100 & 100 & 100 & 100 & 100 & 100 & 100 & 100 & 100 \\
\hline \multicolumn{11}{|l|}{ Current marital status } \\
\hline Never married & 4 & 6 & 9 & 2 & 3 & 2 & 5 & 3 & 6 & 7 \\
\hline Married & 68 & 69 & 43 & 33 & 53 & 64 & 72 & 40 & 71 & 53 \\
\hline In union & 12 & 10 & 22 & 40 & 28 & 15 & 9 & 29 & 13 & 24 \\
\hline Widowed & 4 & 5 & 5 & 3 & 7 & 6 & 7 & 3 & 3 & 2 \\
\hline \multirow[t]{2}{*}{ Divorced/Separated } & 11 & 11 & 21 & 22 & 9 & 13 & 8 & 25 & 7 & 14 \\
\hline & 100 & 100 & 100 & 100 & 100 & 100 & 100 & 100 & 100 & 100 \\
\hline \multicolumn{11}{|c|}{ Number of marriages or unions } \\
\hline Never married & 4 & 6 & 9 & 2 & 3 & 2 & 5 & 3 & 6 & 7 \\
\hline Once & 83 & 81 & 73 & 57 & 80 & 52 & 84 & 61 & 84 & 80 \\
\hline \multirow[t]{2}{*}{ More than once } & 13 & 14 & 18 & 42 & 17 & 46 & 12 & 37 & 10 & 13 \\
\hline & 100 & 100 & 100 & 100 & 100 & 100 & 100 & 100 & 100 & 100 \\
\hline
\end{tabular}

Note: Country-codes are Bolivia (BOL), Brazil (BRA), Colombia (COL), Dominican Republic (DOM), Guatemala (GTM), Haiti (HTI), Mexico (MEX), Nicaragua (NIC), Paraguay (PYR), and Peru (PER) 
Table A3. Comparison of family trajectory types

\begin{tabular}{|c|c|c|c|c|c|c|c|c|c|}
\hline \multirow[b]{2}{*}{ Chracteris tic } & \multicolumn{8}{|c|}{ Family typology } & \multirow[b]{2}{*}{ Total } \\
\hline & $\begin{array}{c}\text { One } \\
\text { transition }\end{array}$ & Latest & $\begin{array}{c}\text { Early- } \\
\text { stop }\end{array}$ & $\begin{array}{c}\text { Delay- } \\
\text { norm }\end{array}$ & Normative & Unstable & Earliest & $\begin{array}{c}\text { Early- } \\
\text { norm }\end{array}$ & \\
\hline CEB & $\begin{array}{r}0.5 \\
(0.1)\end{array}$ & $\begin{array}{r}2.2 \\
(0.1)\end{array}$ & $\begin{array}{r}2.2 \\
(0.0)\end{array}$ & $\begin{array}{r}2.8 \\
(0.1)\end{array}$ & $\begin{array}{r}3.9 \\
(0.1)\end{array}$ & $\begin{array}{r}4.7 \\
(0.2)\end{array}$ & $\begin{array}{r}7.3 \\
(0.2)\end{array}$ & $\begin{array}{r}8.1 \\
(0.2)\end{array}$ & 4 \\
\hline \multicolumn{10}{|c|}{ Current marital status } \\
\hline Never married & $\begin{array}{r}69.4 \\
(3.0)\end{array}$ & $\begin{array}{l}0.0 \\
-\end{array}$ & $\begin{array}{l}0.0 \\
-\end{array}$ & $\begin{array}{l}0.0 \\
-\end{array}$ & $\begin{array}{l}0.0 \\
-\end{array}$ & $\begin{array}{l}0.0 \\
-\end{array}$ & $\begin{array}{l}0.0 \\
-\end{array}$ & $\begin{array}{l}0.0 \\
-\end{array}$ & 7 \\
\hline Married & $\begin{array}{l}15.3 \\
(2.2)\end{array}$ & $\begin{array}{l}51.8 \\
(4.0)\end{array}$ & $\begin{array}{l}37.1 \\
(2.7)\end{array}$ & $\begin{array}{l}71.2 \\
(3.0)\end{array}$ & $\begin{array}{l}83.7 \\
(1.2)\end{array}$ & $\begin{array}{l}14.7 \\
(3.5)\end{array}$ & $\begin{array}{l}42.8 \\
(3.5)\end{array}$ & $\begin{array}{l}89.6 \\
(1.0)\end{array}$ & 52 \\
\hline In union & $\begin{array}{r}7.1 \\
(0.6)\end{array}$ & $\begin{array}{r}27.2 \\
(3.0)\end{array}$ & $\begin{array}{l}17.6 \\
(1.9)\end{array}$ & $\begin{array}{l}13.3 \\
(2.1)\end{array}$ & $\begin{array}{l}0.0 \\
-\end{array}$ & $\begin{array}{l}64.0 \\
(4.4)\end{array}$ & $\begin{array}{l}35.4 \\
(3.3)\end{array}$ & $\begin{array}{r}5.1 \\
(1.0)\end{array}$ & 21 \\
\hline Widowed & $\begin{array}{r}0.9 \\
(0.2)\end{array}$ & $\begin{array}{r}2.2 \\
(0.4)\end{array}$ & $\begin{array}{r}4.4 \\
(0.7)\end{array}$ & $\begin{array}{r}2.4 \\
(0.4)\end{array}$ & $\begin{array}{r}6.2 \\
(0.8)\end{array}$ & $\begin{array}{r}2.0 \\
(0.5)\end{array}$ & $\begin{array}{r}6.3 \\
(0.8)\end{array}$ & $\begin{array}{r}2.6 \\
(0.3)\end{array}$ & 4 \\
\hline Divorce/Sep. & $\begin{array}{r}7.3 \\
(1.0)\end{array}$ & $\begin{array}{l}18.8 \\
(2.1)\end{array}$ & $\begin{array}{r}41.0 \\
(1.8)\end{array}$ & $\begin{array}{l}13.0 \\
(1.4)\end{array}$ & $\begin{array}{l}10.1 \\
(1.0)\end{array}$ & $\begin{array}{l}19.2 \\
(1.3)\end{array}$ & $\begin{array}{l}15.5 \\
(1.3)\end{array}$ & $\begin{array}{r}2.6 \\
(0.2)\end{array}$ & 16 \\
\hline \multicolumn{10}{|c|}{ In union or married } \\
\hline Once & $\begin{array}{l}25.7 \\
(2.1)\end{array}$ & $\begin{array}{l}90.4 \\
(1.6)\end{array}$ & $\begin{array}{l}73.9 \\
(3.1)\end{array}$ & $\begin{array}{r}93.8 \\
(1.1)\end{array}$ & $\begin{array}{r}99.8 \\
(0.0)\end{array}$ & $\begin{array}{l}41.4 \\
(4.7)\end{array}$ & $\begin{array}{l}60.1 \\
(3.6)\end{array}$ & $\begin{array}{r}96.6 \\
(1.6)\end{array}$ & 74 \\
\hline At least twice & $\begin{array}{r}4.8 \\
(1.2)\end{array}$ & $\begin{array}{r}9.6 \\
(1.6)\end{array}$ & $\begin{array}{l}26.1 \\
(3.1)\end{array}$ & $\begin{array}{r}6.2 \\
(1.1)\end{array}$ & $\begin{array}{r}0.2 \\
(0.0)\end{array}$ & $\begin{array}{l}58.6 \\
(4.7)\end{array}$ & $\begin{array}{l}39.9 \\
(3.6)\end{array}$ & $\begin{array}{r}3.4 \\
(1.6)\end{array}$ & 19 \\
\hline \multicolumn{10}{|l|}{ Mean age at: } \\
\hline First marriage & $\begin{array}{l}28.7 \\
(0.7)\end{array}$ & $\begin{array}{l}32.7 \\
(0.2)\end{array}$ & $\begin{array}{l}18.8 \\
(0.2)\end{array}$ & $\begin{array}{l}26.6 \\
(0.1)\end{array}$ & $\begin{array}{l}20.4 \\
(0.0)\end{array}$ & $\begin{array}{l}19.8 \\
(0.2)\end{array}$ & $\begin{array}{l}15.1 \\
(0.1)\end{array}$ & $\begin{array}{l}19.2 \\
(0.1)\end{array}$ & 22 \\
\hline First birth & $\begin{array}{l}26.3 \\
(0.3)\end{array}$ & $\begin{array}{l}32.8 \\
(0.3)\end{array}$ & $\begin{array}{c}20.4 \\
(0.1)\end{array}$ & $\begin{array}{l}28.1 \\
(0.1)\end{array}$ & $\begin{array}{c}21.8 \\
(0.1)\end{array}$ & $\begin{array}{l}21.4 \\
(0.1)\end{array}$ & $\begin{array}{l}16.4 \\
(0.0)\end{array}$ & $\begin{array}{l}20.7 \\
(0.1)\end{array}$ & 23 \\
\hline Last birth & $\begin{array}{l}30.3 \\
(0.2)\end{array}$ & $\begin{array}{l}36.9 \\
(0.2)\end{array}$ & $\begin{array}{c}23.6 \\
(0.1)\end{array}$ & $\begin{array}{l}34.3 \\
(0.2)\end{array}$ & $\begin{array}{l}31.4 \\
(0.1)\end{array}$ & $\begin{array}{l}34.1 \\
(0.3)\end{array}$ & $\begin{array}{l}33.5 \\
(0.3)\end{array}$ & $\begin{array}{l}38.8 \\
(0.2)\end{array}$ & 32 \\
\hline \multicolumn{10}{|l|}{ Parity level } \\
\hline Zero & $\begin{array}{l}73.3 \\
(2.6)\end{array}$ & $\begin{array}{l}0.0 \\
-\end{array}$ & $\begin{array}{l}0.0 \\
-\end{array}$ & $\begin{array}{l}0.0 \\
-\end{array}$ & $\begin{array}{l}0.0 \\
-\end{array}$ & $\begin{array}{l}0.0 \\
-\end{array}$ & $\begin{array}{l}0.0 \\
-\end{array}$ & $\begin{array}{l}0.0 \\
-\end{array}$ & 7 \\
\hline One & $\begin{array}{l}16.3 \\
(2.0)\end{array}$ & $\begin{array}{l}40.7 \\
(2.0)\end{array}$ & $\begin{array}{l}26.0 \\
(1.3)\end{array}$ & $\begin{array}{l}13.3 \\
(1.0)\end{array}$ & $\begin{array}{r}0.2 \\
(0.1)\end{array}$ & $\begin{array}{r}1.0 \\
(0.1)\end{array}$ & $\begin{array}{r}0.1 \\
(0.0)\end{array}$ & $\begin{array}{l}0.0 \\
-\end{array}$ & 10 \\
\hline Two & $\begin{array}{r}5.0 \\
(0.7)\end{array}$ & $\begin{array}{l}33.8 \\
(1.5)\end{array}$ & $\begin{array}{l}39.0 \\
(2.0)\end{array}$ & $\begin{array}{l}39.2 \\
(3.2)\end{array}$ & $\begin{array}{l}12.3 \\
(1.4)\end{array}$ & $\begin{array}{r}7.4 \\
(1.0)\end{array}$ & $\begin{array}{r}1.3 \\
(0.2)\end{array}$ & $\begin{array}{r}0.3 \\
(0.1)\end{array}$ & 18 \\
\hline 3 to 4 & $\begin{array}{r}3.8 \\
(0.4)\end{array}$ & $\begin{array}{l}18.2 \\
(1.5)\end{array}$ & $\begin{array}{l}33.4 \\
(2.1)\end{array}$ & $\begin{array}{l}34.2 \\
(1.6)\end{array}$ & $\begin{array}{l}57.7 \\
(1.5)\end{array}$ & $\begin{array}{l}42.6 \\
(2.9)\end{array}$ & $\begin{array}{l}16.0 \\
(2.2)\end{array}$ & $\begin{array}{r}7.6 \\
(1.8)\end{array}$ & 33 \\
\hline 5 to 6 & $\begin{array}{r}1.0 \\
(0.3)\end{array}$ & $\begin{array}{r}3.9 \\
(0.7)\end{array}$ & $\begin{array}{r}1.5 \\
(0.2)\end{array}$ & $\begin{array}{l}10.8 \\
(2.0)\end{array}$ & $\begin{array}{l}29.6 \\
(2.6)\end{array}$ & $\begin{array}{l}35.9 \\
(1.9)\end{array}$ & $\begin{array}{l}22.5 \\
(1.5)\end{array}$ & $\begin{array}{l}11.5 \\
(1.1)\end{array}$ & 18 \\
\hline $7+$ & $\begin{array}{r}0.7 \\
(0.4) \\
\end{array}$ & $\begin{array}{r}3.4 \\
(0.9) \\
\end{array}$ & $\begin{array}{r}0.0 \\
(0.0) \\
\end{array}$ & $\begin{array}{r}2.5 \\
(0.7) \\
\end{array}$ & $\begin{array}{r}0.3 \\
(0.1) \\
\end{array}$ & $\begin{array}{l}13.1 \\
(2.2) \\
\end{array}$ & $\begin{array}{r}60.2 \\
(3.8) \\
\end{array}$ & $\begin{array}{r}80.6 \\
(2.7) \\
\end{array}$ & 15 \\
\hline Percent & 9.6 & 5.7 & 12.9 & 15.4 & 22.2 & 15.5 & 11.5 & 7.1 & 100 \\
\hline
\end{tabular}

Note: CEB stands for children ever born. Standard errors, in parentheses, account for the sample design. 
Figure A2. Family profiles by origin, age at migration and educational attainment in Large cities - Birth cohorts: 1945-1965

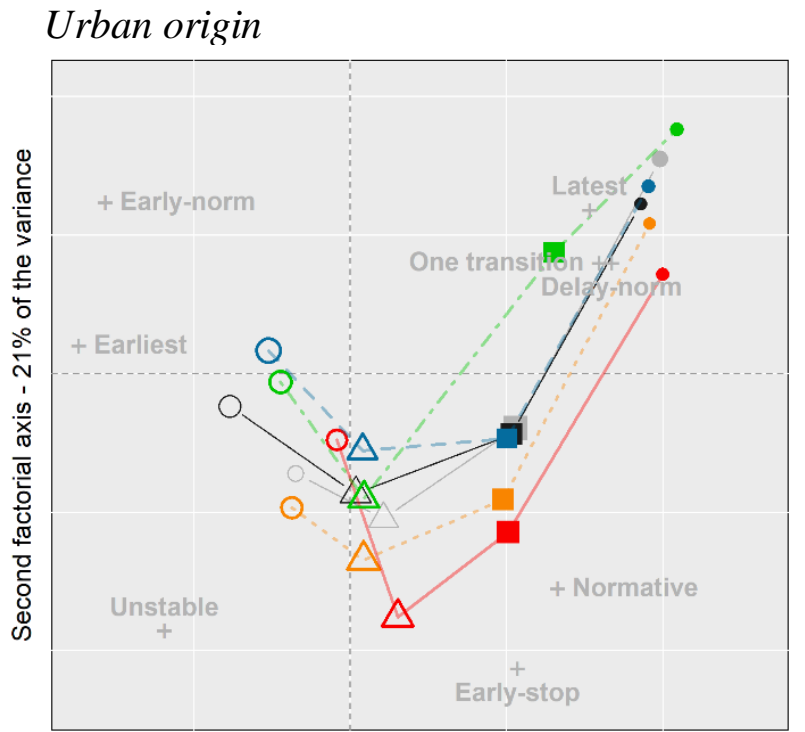

First factorial axis - $60 \%$ of the variance

Years of schooling

○ $0-4 \triangle 5-8 \quad 9-12 \cdot 13+$

Age at migration

Non-migrant at origin

Before age 18

19-24
Rural origin

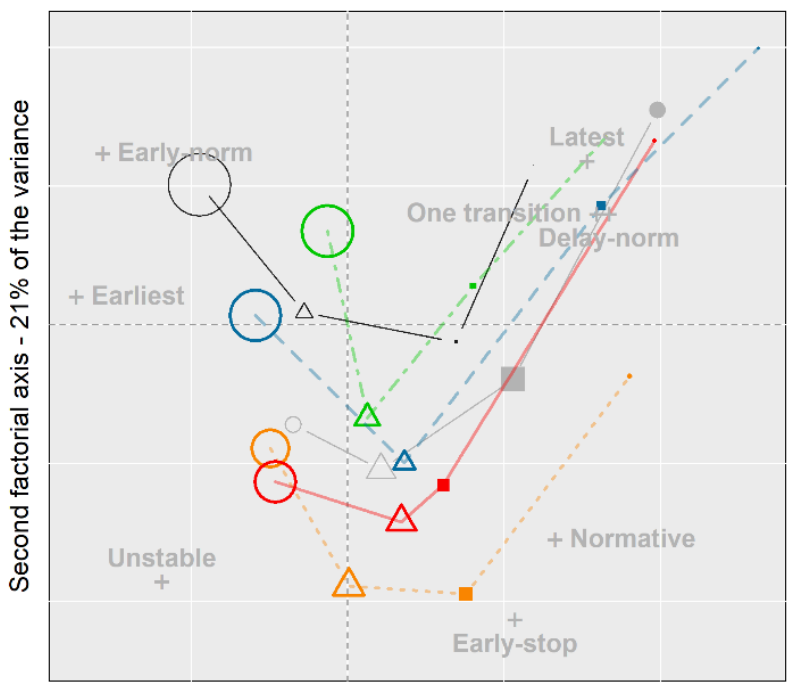

First factorial axis $-60 \%$ of the variance

Relative size

25\% \ $50 \%$ D5\%

- - 25-30

- After age 30

Notes: The percentages of variance of the axes refer to the total variance across the 108 family profiles, i.e., to the total sum of squared Euclidean distances of the PCA-coordinates. There were no significance patterns along the third axis (6\% of the total variance). 
Figure A3. Family profiles by origin, age at migration, and educational attainment in Urban areas - Birth cohorts: 1945-1965

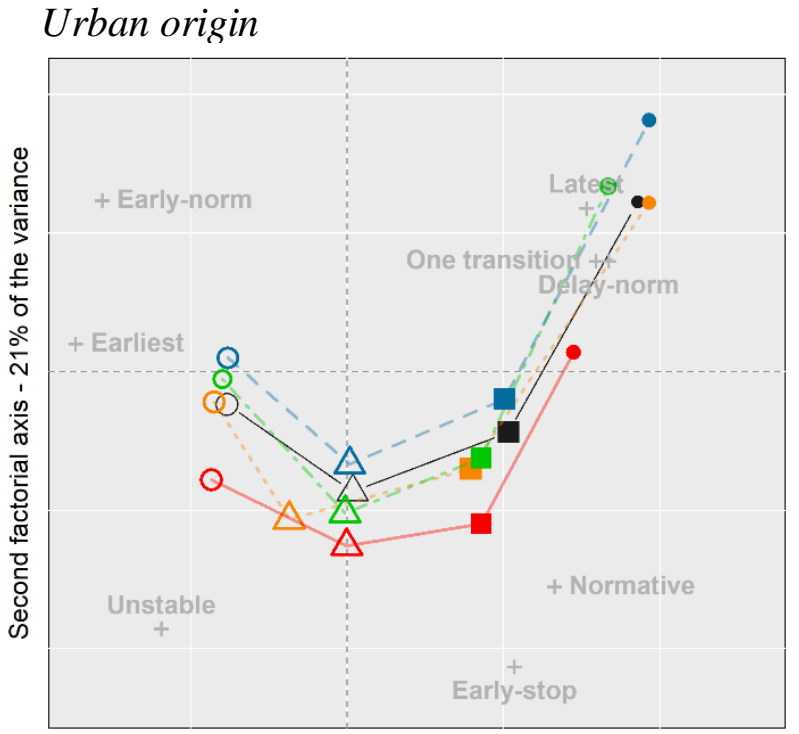

First factorial axis $-60 \%$ of the variance
Rural origin

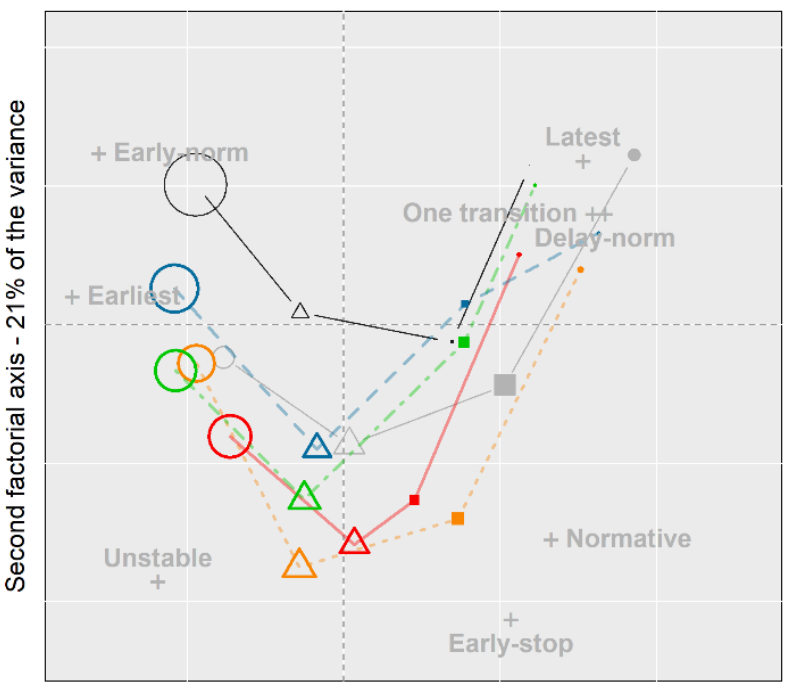

First factorial axis $-60 \%$ of the variance

Relative size

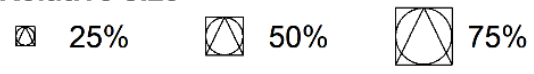

Years of schooling

○ 0-4 $\triangle 5-8$ - 9-12 • 13+

Age at migration

- Non-migrant at origin

-..- Before age 18

Non-migrant at destination
$--25-30$

- - After age 30

Notes: The percentages of variance of the axes refer to the total variance across the 108 family profiles, i.e., to the total sum of squared Euclidean distances of the PCA-coordinates. There were no significance patterns along the third axis (6\% of the total variance). 
Figure A4. Family profiles by origin, age at migration, and educational attainment in Rural areas - Birth cohorts: 1945-1965

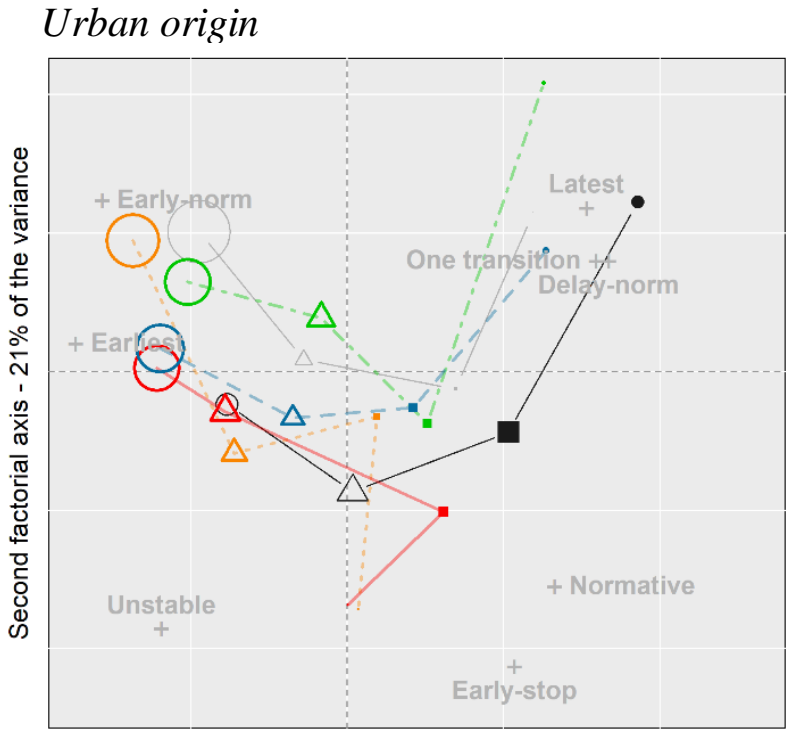

First factorial axis $-60 \%$ of the variance

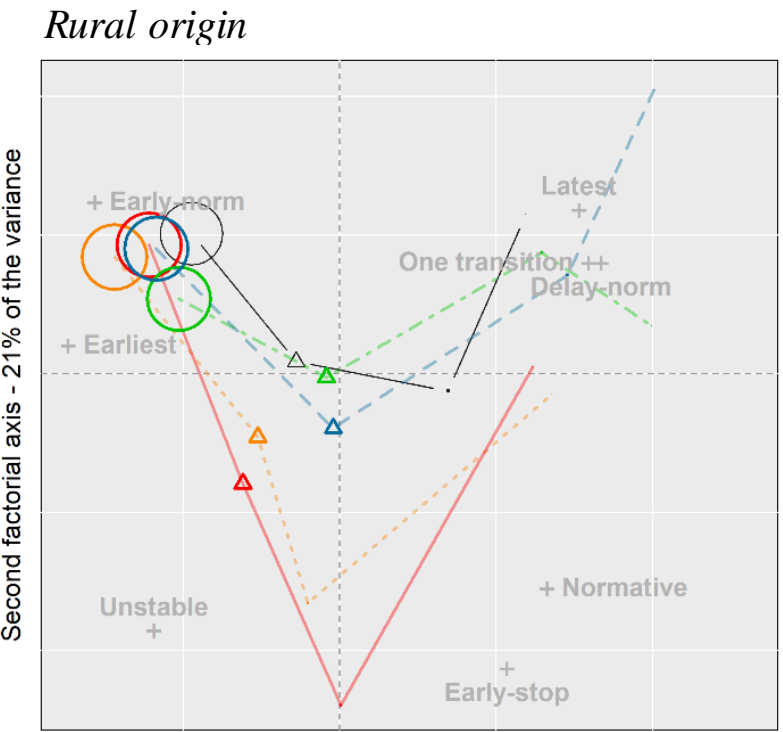

First factorial axis - $60 \%$ of the variance

\section{Years of schooling}

० 0-4 $\triangle 5-8 \quad 9-12 \cdot 13+$

Age at migration

- Non-migrant at origin

- - Before age 18

- Non-migrant at destination — 19-24

Relative size

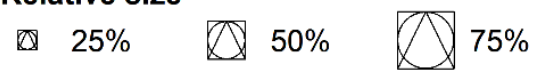

- $25-30$

- - After age 30

Notes: The percentages of variance of the axes refer to the total variance across the 108 family profiles, i.e., to the total sum of squared Euclidean distances of the PCA-coordinates. There were no significance patterns along the third axis (6\% of the total variance). 
Table A4: Family profiles for women in large cities by migration status, origin, age at migration, and years of schooling

\begin{tabular}{|c|c|c|c|c|c|c|c|c|}
\hline \multirow{3}{*}{$\begin{array}{r}\text { Years of } \\
\text { schooling }\end{array}$} & \multicolumn{8}{|c|}{ Non-migrants } \\
\hline & & & & Family & typology & & & \\
\hline & $\begin{array}{c}\text { One } \\
\text { transition }\end{array}$ & Latest & $\begin{array}{l}\text { Early- } \\
\text { stop }\end{array}$ & $\begin{array}{l}\text { Delay- } \\
\text { norm }\end{array}$ & Normative & Unstable & Earliest & $\begin{array}{l}\text { Early- } \\
\text { norm }\end{array}$ \\
\hline \multirow[t]{2}{*}{0 to 4} & 7.9 & 3.2 & 12.4 & 5.7 & 18.4 & 17.4 & 21.6 & 13.3 \\
\hline & (4.8) & $(0.5)$ & $(0.3)$ & (0.6) & (0.4) & (0.7) & $(0.8)$ & (0.6) \\
\hline \multirow[t]{2}{*}{5 to 8} & 7.7 & 3.3 & 15.7 & 10.9 & 23.7 & 16.2 & 15.4 & 7.1 \\
\hline & (3.8) & $(0.4)$ & $(0.3)$ & (0.6) & $(0.5)$ & (0.6) & $(0.6)$ & (0.4) \\
\hline \multirow[t]{2}{*}{9 to 12} & 11.7 & 5.2 & 14.9 & 17.8 & 25.5 & 14.5 & 6.4 & 4.0 \\
\hline & (3.4) & $(0.5)$ & $(0.3)$ & $(0.5)$ & $(0.6)$ & $(0.5)$ & (0.4) & (0.3) \\
\hline \multirow{2}{*}{$13+$} & 20.5 & 11.7 & 10.3 & 26.4 & 19.5 & 7.8 & 1.8 & 2.0 \\
\hline & $(4.2)$ & $(0.7)$ & $(0.5)$ & $(0.5)$ & $(0.7)$ & (0.4) & $(0.2)$ & $(0.2)$ \\
\hline
\end{tabular}

\begin{tabular}{|c|c|c|c|c|c|c|c|c|c|c|c|c|c|c|c|c|c|}
\hline \multirow{2}{*}{\multicolumn{2}{|c|}{$\begin{array}{c}\text { Age at } \\
\text { migration } \\
\text { and years of } \\
\text { schooling }\end{array}$}} & \multicolumn{8}{|c|}{ Migrants of urban origin } & \multicolumn{8}{|c|}{ Migrants of rural origin } \\
\hline & & \multirow{2}{*}{$\begin{array}{r}\begin{array}{c}\text { One } \\
\text { transition }\end{array} \\
6.3\end{array}$} & \multirow{2}{*}{$\begin{array}{r}\text { Latest } \\
2.8 \\
(0.7)\end{array}$} & \multirow{2}{*}{$\begin{array}{r}\begin{array}{l}\text { Early- } \\
\text { stop }\end{array} \\
13.4 \\
(0.5)\end{array}$} & \multirow{2}{*}{$\begin{array}{r}\begin{array}{l}\text { Delay- } \\
\text { norm }\end{array} \\
9.2 \\
(0.9)\end{array}$} & \multirow{2}{*}{$\begin{array}{r}\text { Normative } \\
\begin{array}{l}17.5 \\
(0.8)\end{array}\end{array}$} & \multirow{2}{*}{$\begin{array}{r}\text { Unstable } \\
\begin{array}{l}17.2 \\
(1.0)\end{array}\end{array}$} & \multirow{2}{*}{$\begin{array}{r}\text { Earliest } \\
25.5 \\
(1.2)\end{array}$} & \multirow{2}{*}{$\begin{array}{r}\begin{array}{r}\text { Early- } \\
\text { norm }\end{array} \\
8.0 \\
(0.8)\end{array}$} & \multirow{2}{*}{$\begin{array}{r}\begin{array}{c}\text { One } \\
\text { transition }\end{array} \\
9.1 \\
(9.0)\end{array}$} & \multirow{2}{*}{$\begin{array}{r}\text { Latest } \\
2.7 \\
(1.0)\end{array}$} & \multirow{2}{*}{$\begin{array}{r}\begin{array}{c}\text { Early- } \\
\text { stop }\end{array} \\
10.6 \\
(0.6)\end{array}$} & \multirow{2}{*}{$\begin{array}{r}\begin{array}{l}\text { Delay- } \\
\text { norm }\end{array} \\
7.0 \\
(1.1)\end{array}$} & \multirow{2}{*}{$\begin{array}{r}\text { Normative } \\
19.4 \\
(0.9)\end{array}$} & \multirow{2}{*}{$\begin{array}{r}\text { Unstable } \\
20.2 \\
(1.4)\end{array}$} & \multirow{2}{*}{$\begin{array}{r}\text { Earliest } \\
16.1 \\
(1.3)\end{array}$} & \multirow{2}{*}{$\begin{array}{r}\begin{array}{l}\text { Early- } \\
\text { norm }\end{array} \\
15.0 \\
(1.3)\end{array}$} \\
\hline$<18$ & 0 to 4 & & & & & & & & & & & & & & & & \\
\hline & 5 to 8 & 6.3 & 4.0 & 14.7 & 12.1 & 21.6 & 21.6 & 14.3 & 5.4 & 4.3 & 3.1 & 15.1 & 9.2 & 25.2 & $\begin{array}{l}(1.4) \\
23.8\end{array}$ & $\begin{array}{l}(1.3) \\
13.1\end{array}$ & 6.1 \\
\hline & & (6.5) & $(0.6)$ & $(0.5)$ & $(0.9)$ & $(0.9)$ & (1.1) & $(0.9)$ & $(0.6)$ & (10.4) & $(0.9)$ & $(0.8)$ & (1.6) & (1.3) & (1.9) & (1.5) & (1.1) \\
\hline & 9 to 12 & 9.5 & 6.5 & 16.5 & 14.5 & 26.6 & 16.7 & 6.2 & 3.5 & 6.8 & 2.1 & 17.9 & 16.2 & 28.6 & 20.1 & 3.1 & 5.2 \\
\hline & & (6.3) & $(0.8)$ & $(0.7)$ & (1.0) & $(1.0)$ & $(1.0)$ & $(0.7)$ & $(0.5)$ & (12.5) & (1.4) & $(0.8)$ & (2.2) & (2.1) & (2.3) & (1.0) & (1.3) \\
\hline & $13+$ & 19.1 & 9.8 & 13.8 & 28.3 & 16.5 & 9.2 & 0.9 & 2.4 & 14.6 & 10.3 & 18.2 & 26.5 & 20.7 & 9.6 & 0.1 & 0.1 \\
\hline & & (9.3) & (1.4) & $(1.0)$ & (1.2) & (1.6) & $(1.0)$ & $(0.3)$ & $(0.5)$ & (22.9) & (3.3) & (2.8) & (3.6) & $(4.1)$ & (2.7) & $(0.3)$ & $(0.3)$ \\
\hline $19-24$ & 0 to 4 & 4.5 & 3.7 & 12.8 & 9.3 & 19.2 & 16.1 & 19.4 & 15.1 & 5.3 & 2.5 & 8.7 & 6.8 & 23.6 & 27.7 & 14.4 & 11.0 \\
\hline & & (9.1) & $(0.7)$ & $(0.7)$ & (1.2) & $(1.0)$ & (1.3) & (1.4) & (1.3) & (8.5) & $(0.8)$ & $(0.6)$ & (1.0) & $(0.9)$ & (1.6) & (1.3) & (1.1) \\
\hline & 5 to 8 & 3.2 & 2.7 & 17.6 & 10.5 & 30.0 & 18.7 & 11.1 & 6.2 & 6.7 & 2.3 & 15.5 & 12.4 & 25.1 & 22.2 & 10.7 & 5.0 \\
\hline & & (7.4) & $(0.6)$ & $(0.6)$ & (1.3) & $(1.0)$ & (1.3) & (1.1) & $(0.8)$ & (11.6) & (1.3) & $(0.7)$ & (1.8) & (1.7) & (2.1) & (1.6) & (1.1) \\
\hline & 9 to 12 & 8.1 & 4.2 & 16.8 & 17.3 & 30.9 & 15.8 & 4.1 & 2.8 & 9.3 & 3.4 & 15.6 & 21.4 & 21.0 & 20.1 & 4.7 & 4.4 \\
\hline & & $(7.2)$ & $(0.9)$ & $(0.7)$ & $(1.2)$ & (1.3) & $(1.2)$ & $(0.7)$ & $(0.6)$ & $(16.0)$ & (1.9) & $(1.2)$ & (2.4) & (2.7) & (2.6) & (1.4) & (1.3) \\
\hline & $13+$ & 10.2 & 13.5 & 13.5 & 28.9 & 25.7 & 6.1 & 1.4 & 0.7 & 6.8 & 9.8 & 8.3 & 39.7 & 23.2 & 12.0 & 0.1 & 0.1 \\
\hline & & (9.6) & (1.3) & (1.4) & (1.4) & (1.9) & $(1.0)$ & $(0.5)$ & $(0.3)$ & (24.4) & (2.6) & (3.1) & (2.8) & (5.0) & (3.3) & $(0.3)$ & $(0.3)$ \\
\hline 25-30 & 0 to 4 & 6.8 & 2.2 & 6.9 & 13.2 & 17.8 & 19.6 & 18.9 & 14.6 & 5.6 & 4.0 & 7.3 & 19.7 & 15.1 & 15.4 & 20.1 & 12.7 \\
\hline & & (10.4) & $(1.0)$ & $(0.6)$ & $(1.0)$ & (1.4) & (1.6) & (1.6) & (1.4) & (11.2) & $(0.9)$ & $(0.8)$ & (1.0) & (1.6) & (1.4) & (1.6) & (1.3) \\
\hline & 5 to 8 & 3.8 & 3.9 & 14.7 & 16.1 & 22.0 & 19.9 & 12.2 & 7.4 & 5.3 & 6.8 & 13.1 & 18.5 & 15.1 & 22.9 & 9.9 & 8.5 \\
\hline & & (9.3) & $(0.7)$ & $(0.7)$ & (1.4) & (1.4) & (1.5) & (1.3) & $(1.0)$ & (18.0) & (1.4) & (1.6) & (2.2) & (2.5) & (2.7) & (1.9) & (1.8) \\
\hline & 9 to 12 & 9.7 & 9.7 & 11.7 & 30.7 & 16.6 & 13.9 & 3.6 & 4.1 & 5.6 & 11.7 & 4.0 & 19.3 & 32.5 & 19.4 & 5.9 & 1.7 \\
\hline & & (10.8) & $(1.2)$ & $(1.2)$ & (1.3) & (1.9) & (1.4) & $(0.8)$ & $(0.8)$ & (22.1) & (2.4) & (3.3) & (2.0) & $(4.1)$ & (4.1) & (2.4) & (1.3) \\
\hline & $13+$ & 11.9 & 12.5 & 10.9 & 36.7 & 18.6 & 5.9 & 1.7 & 1.7 & 10.0 & 8.6 & 0.2 & 22.4 & 48.3 & 10.0 & 0.2 & 0.2 \\
\hline & & (12.1) & $(1.5)$ & (1.6) & (1.5) & $(2.3)$ & $(1.1)$ & $(0.6)$ & $(0.6)$ & (31.4) & (4.7) & $(4.4)$ & $(0.7)$ & (6.6) & (4.7) & $(0.8)$ & $(0.8)$ \\
\hline$>30$ & 0 to 4 & 5.7 & 4.9 & 8.4 & 9.5 & 16.5 & 17.6 & 25.3 & 12.2 & 5.4 & 4.7 & 7.6 & 7.9 & 17.4 & 18.1 & 20.8 & 18.1 \\
\hline & & $(7.5)$ & $(0.6)$ & $(0.6)$ & $(0.8)$ & $(0.8)$ & $(1.1)$ & $(1.2)$ & $(0.9)$ & $(7.8)$ & $(0.7)$ & $(0.6)$ & $(0.8)$ & $(0.8)$ & (1.1) & $(1.2)$ & (1.1) \\
\hline & 5 to 8 & 6.3 & 5.5 & 13.1 & 9.7 & 24.0 & 15.9 & 14.8 & 10.6 & 5.1 & 6.1 & 15.2 & 9.7 & 24.7 & 17.2 & 11.8 & 10.1 \\
\hline & & (6.9) & $(0.7)$ & $(0.7)$ & $(1.0)$ & $(0.9)$ & $(1.1)$ & (1.1) & $(0.9)$ & (11.8) & $(1.1)$ & $(1.2)$ & (1.8) & $(1.5)$ & (1.9) & (1.6) & $(1.5)$ \\
\hline & 9 to 12 & 8.8 & 6.5 & 14.4 & 15.6 & 29.6 & 13.3 & 6.2 & 5.4 & 10.2 & 11.9 & 13.2 & 23.3 & 21.4 & 10.4 & 6.1 & 3.4 \\
\hline & & (6.8) & $(0.9)$ & $(0.8)$ & (1.1) & $(1.1)$ & $(1.1)$ & $(0.8)$ & $(0.7)$ & (16.5) & $(2.0)$ & $(2.2)$ & (2.3) & (2.9) & (2.1) & (1.6) & $(1.2)$ \\
\hline & $13+$ & 16.7 & 12.5 & 6.4 & 26.1 & 26.7 & 7.1 & 2.3 & 2.2 & 17.4 & 14.9 & 11.1 & 32.3 & 18.5 & 5.5 & 0.1 & 0.1 \\
\hline & & $(8.0)$ & $(1.3)$ & $(1.2)$ & $(0.9)$ & $(1.6)$ & $(0.9)$ & $(0.5)$ & $(0.5)$ & (28.7) & $(4.2)$ & $(4.0)$ & (3.5) & $(5.2)$ & (2.5) & $(0.4)$ & $(0.4)$ \\
\hline
\end{tabular}

Note: Standard errors, in parentheses, account for the sample design. 
Table A5: Family profiles for women in urban areas by migration status, origin, age at migration, and years of schooling

\begin{tabular}{|c|c|c|c|c|c|c|c|c|}
\hline \multirow{3}{*}{$\begin{array}{c}\text { Years of } \\
\text { schooling }\end{array}$} & \\
\hline & & \multicolumn{7}{|c|}{ Non-migrants } \\
\hline & $\begin{array}{c}\text { One } \\
\text { transition }\end{array}$ & Latest & $\begin{array}{c}\text { Early- } \\
\text { stop }\end{array}$ & $\begin{array}{l}\text { Delay- } \\
\text { norm }\end{array}$ & Normative & Unstable & Earliest & $\begin{array}{c}\text { Early- } \\
\text { norm }\end{array}$ \\
\hline \multirow[t]{2}{*}{0 to 4} & 7.1 & 3.2 & 10.0 & 5.1 & 14.2 & 17.7 & 27.7 & 15.1 \\
\hline & (4.8) & $(0.4)$ & $(0.3)$ & $(0.5)$ & $(0.4)$ & $(0.6)$ & $(0.8)$ & $(0.6)$ \\
\hline \multirow[t]{2}{*}{5 to 8} & 7.8 & 3.0 & 12.8 & 9.9 & 24.0 & 17.9 & 15.1 & 9.5 \\
\hline & (3.9) & $(0.4)$ & $(0.3)$ & $(0.6)$ & $(0.5)$ & $(0.6)$ & (0.6) & $(0.5)$ \\
\hline \multirow[t]{2}{*}{9 to 12} & 11.6 & 5.7 & 14.4 & 15.0 & 27.8 & 15.0 & 5.7 & 4.8 \\
\hline & (3.7) & $(0.5)$ & $(0.4)$ & (0.6) & $(0.6)$ & $(0.6)$ & $(0.4)$ & $(0.4)$ \\
\hline \multirow[t]{2}{*}{$13+$} & 17.2 & 11.1 & 10.4 & 26.3 & 22.3 & 9.0 & 1.6 & 2.1 \\
\hline & $(4.9)$ & $(0.8)$ & $(0.6)$ & $(0.6)$ & $(0.9)$ & $(0.6)$ & $(0.3)$ & $(0.3)$ \\
\hline
\end{tabular}

\begin{tabular}{|c|c|c|c|c|c|c|c|c|c|c|c|c|c|c|c|c|c|}
\hline \multirow{3}{*}{\multicolumn{2}{|c|}{$\begin{array}{c}\text { Age at } \\
\text { migration } \\
\text { and years of } \\
\text { schooling }\end{array}$}} & \multirow{2}{*}{\multicolumn{8}{|c|}{ Migrants of urban origin }} & \multirow{2}{*}{\multicolumn{8}{|c|}{ Migrants of rural origin }} \\
\hline & & & & & & & & & & & & & & & & & \\
\hline & & \multirow{2}{*}{$\begin{array}{r}\begin{array}{c}\text { One } \\
\text { transition }\end{array} \\
4.9\end{array}$} & \multirow{2}{*}{$\begin{array}{r}\text { Latest } \\
1.7\end{array}$} & \multirow{2}{*}{$\begin{array}{r}\begin{array}{l}\text { Early- } \\
\text { stop }\end{array} \\
8.8\end{array}$} & \multirow{2}{*}{$\begin{array}{l}\begin{array}{l}\text { Delay- } \\
\text { norm }\end{array} \\
5.0\end{array}$} & Normative & \multirow{2}{*}{$\begin{array}{r}\text { Unstable } \\
17.5\end{array}$} & \multirow{2}{*}{$\begin{array}{r}\text { Earliest } \\
32.4\end{array}$} & \multirow{2}{*}{$\begin{array}{r}\begin{array}{l}\text { Early- } \\
\text { norm }\end{array} \\
12.4\end{array}$} & \multirow{2}{*}{$\begin{array}{r}\begin{array}{c}\text { One } \\
\text { transition }\end{array} \\
3.2\end{array}$} & \multirow{2}{*}{$\begin{array}{r}\text { Latest } \\
1.1\end{array}$} & \multirow{2}{*}{$\begin{array}{l}\begin{array}{c}\text { Early- } \\
\text { stop }\end{array} \\
11.6\end{array}$} & \multirow{2}{*}{$\begin{array}{r}\begin{array}{l}\text { Delay- } \\
\text { norm }\end{array} \\
5.0\end{array}$} & \multirow{2}{*}{$\begin{array}{r}\text { Normative } \\
13.6\end{array}$} & \multirow{2}{*}{$\begin{array}{r}\text { Unstable } \\
16.6\end{array}$} & \multirow{2}{*}{$\begin{array}{r}\text { Earliest } \\
33.9\end{array}$} & \multirow{2}{*}{\begin{tabular}{|r}
$\begin{array}{l}\text { Early- } \\
\text { norm }\end{array}$ \\
14.9
\end{tabular}} \\
\hline$<18$ & 0 to 4 & & & & & 17.3 & & & & & & & & & & & \\
\hline & & $(10.0)$ & $(0.8)$ & & (1.1) & $(0.8)$ & (1.4) & (1.8) & $(1.2)$ & (10.4) & $(0.6)$ & & (1.1) & $(0.8)$ & $(1.3)$ & (1.7) & (1.3) \\
\hline & 5 to 8 & 6.7 & 2.3 & 13.6 & 6.0 & 21.8 & 20.2 & 20.0 & 9.3 & 2.5 & 3.2 & 16.6 & 5.5 & 24.2 & 22.0 & 16.7 & 9.4 \\
\hline & & (8.4) & $(0.9)$ & $(0.5)$ & $(1.2)$ & $(0.8)$ & (1.4) & (1.4) & (1.0) & (10.4) & (0.7) & $(0.8)$ & (1.7) & $(1.0)$ & (1.8) & (1.7) & (1.3) \\
\hline & 9 to 12 & 7.6 & 3.6 & 14.2 & 17.2 & 29.0 & 17.0 & 6.7 & 4.7 & 7.4 & 3.5 & 19.2 & 11.8 & 31.2 & 14.6 & 8.1 & 4.3 \\
\hline & & (7.7) & $(0.9)$ & $(0.6)$ & (1.2) & (1.3) & (1.3) & (0.9) & $(0.7)$ & (13.0) & (1.6) & (1.1) & (2.4) & (1.9) & (2.1) & (1.6) & (1.2) \\
\hline & $13+$ & 15.0 & 12.0 & 11.3 & 23.1 & 26.2 & 9.1 & 1.4 & 1.9 & 11.8 & 9.6 & 10.0 & 22.9 & 27.1 & 14.5 & 1.9 & 2.1 \\
\hline & & (9.7) & (1.5) & (1.4) & (1.4) & (1.8) & (1.2) & $(0.5)$ & $(0.6)$ & (19.8) & (2.8) & (2.6) & (2.6) & (3.7) & (3.1) & (1.2) & (1.3) \\
\hline $19-24$ & 0 to 4 & 3.0 & 2.6 & 9.3 & 3.6 & 18.6 & 23.7 & 20.9 & 18.2 & 2.7 & 2.5 & 8.5 & 4.9 & 22.4 & 22.2 & 23.1 & 13.7 \\
\hline & & (11.1) & $(0.7)$ & $(0.7)$ & (1.3) & $(0.8)$ & (1.8) & (1.8) & (1.7) & (8.6) & $(0.6)$ & $(0.6)$ & $(1.0)$ & $(0.8)$ & (1.5) & (1.5) & (1.2) \\
\hline & 5 to 8 & 4.8 & 2.0 & 12.2 & 7.4 & 31.4 & 18.8 & 12.8 & 10.6 & 3.7 & 0.8 & 14.8 & 9.7 & 31.3 & 19.5 & 12.4 & 7.8 \\
\hline & & (8.8) & $(0.9)$ & $(0.6)$ & (1.3) & (1.1) & (1.6) & (1.4) & (1.3) & (10.6) & $(0.9)$ & $(0.4)$ & (1.7) & (1.5) & (2.0) & (1.6) & (1.3) \\
\hline & 9 to 12 & 5.5 & 3.9 & 15.6 & 12.4 & 34.3 & 17.5 & 4.8 & 6.0 & 7.6 & 3.0 & 13.9 & 10.8 & 31.4 & 22.3 & 3.9 & 7.2 \\
\hline & & (8.6) & $(0.9)$ & $(0.8)$ & (1.5) & (1.4) & (1.6) & $(0.9)$ & $(1.0)$ & (15.0) & (1.8) & (1.2) & (2.4) & $(2.2)$ & (2.9) & (1.3) & (1.8) \\
\hline & $13+$ & 9.4 & 6.1 & 10.9 & 21.4 & 36.4 & 10.0 & 1.2 & 4.7 & 12.7 & 4.2 & 6.7 & 25.1 & 32.6 & 10.6 & 0.5 & 7.5 \\
\hline & & (9.7) & (1.4) & (1.1) & (1.4) & (1.9) & (1.4) & $(0.5)$ & $(1.0)$ & (21.4) & (3.4) & $(2.0)$ & $(2.5)$ & (4.4) & (3.1) & $(0.7)$ & (2.7) \\
\hline $25-30$ & 0 to 4 & 2.7 & 1.4 & 9.2 & 7.6 & 15.4 & 19.4 & 28.8 & 15.6 & 4.5 & 1.6 & 7.4 & 7.4 & 14.5 & 21.3 & 28.2 & 15.3 \\
\hline & & (13.6) & $(0.8)$ & $(0.6)$ & (1.4) & $(1.3)$ & (1.9) & $(2.2)$ & (1.8) & (10.9) & $(0.8)$ & $(0.5)$ & $(1.0)$ & $(1.0)$ & (1.6) & (1.7) & (1.4) \\
\hline & 5 to 8 & 4.2 & 2.5 & 12.2 & 14.4 & 23.6 & 20.5 & 15.0 & 7.5 & 4.5 & 3.2 & 9.0 & 12.0 & 23.4 & 25.2 & 13.4 & 9.4 \\
\hline & & (10.2) & $(0.9)$ & $(0.7)$ & (1.4) & $(1.5)$ & (1.7) & $(1.5)$ & $(1.1)$ & (12.1) & (1.1) & $(0.9)$ & $(1.5)$ & (1.7) & (2.2) & $(1.7)$ & (1.5) \\
\hline & 9 to 12 & 6.5 & 3.4 & 12.6 & 22.9 & 27.3 & 18.9 & 4.2 & 4.2 & 9.7 & 3.7 & 9.8 & 22.2 & 25.5 & 17.9 & 6.4 & 4.8 \\
\hline & & (10.1) & (1.1) & $(0.8)$ & $(1.5)$ & (1.9) & (1.8) & $(0.9)$ & $(0.9)$ & (16.6) & (2.1) & (1.4) & $(2.1)$ & $(3.0)$ & (2.8) & $(1.8)$ & (1.5) \\
\hline & $13+$ & 12.7 & 9.2 & 9.3 & 35.9 & 18.5 & 11.7 & 0.9 & 1.8 & 7.5 & 3.4 & 6.6 & 38.1 & 22.9 & 10.5 & 7.1 & 3.9 \\
\hline & & (11.9) & (1.5) & (1.3) & (1.3) & $(2.2)$ & $(1.5)$ & (0.4) & $(0.6)$ & (27.2) & (3.0) & $(2.1)$ & $(2.8)$ & $(5.6)$ & (3.5) & (2.9) & $(2.2)$ \\
\hline$>30$ & 0 to 4 & 4.6 & 5.4 & 7.9 & 6.5 & 14.4 & 17.8 & 29.6 & 13.7 & 3.5 & 3.7 & 6.3 & 5.7 & 12.3 & 18.8 & 28.5 & 21.2 \\
\hline & & (9.6) & $(0.7)$ & $(0.8)$ & $(0.9)$ & $(0.8)$ & (1.3) & (1.5) & $(1.2)$ & (7.7) & $(0.5)$ & $(0.5)$ & $(0.6)$ & $(0.6)$ & $(1.0)$ & (1.1) & (1.0) \\
\hline & 5 to 8 & 6.5 & 5.1 & 13.4 & 9.8 & 21.1 & 19.1 & 14.2 & 10.6 & 6.2 & 3.8 & 10.9 & 9.6 & 21.4 & 22.0 & 16.0 & 10.1 \\
\hline & & (7.9) & $(0.8)$ & $(0.7)$ & (1.1) & $(1.0)$ & $(1.3)$ & $(1.1)$ & $(1.0)$ & $(9.3)$ & $(0.9)$ & $(0.7)$ & $(1.2)$ & $(1.1)$ & (1.6) & (1.4) & (1.2) \\
\hline & 9 to 12 & 6.4 & 9.0 & 13.2 & 16.6 & 27.4 & 14.6 & 7.2 & 5.6 & 9.5 & 9.3 & 9.0 & 16.3 & 22.7 & 20.1 & 6.7 & 6.3 \\
\hline & & (7.4) & $(0.8)$ & $\begin{array}{l}(0.9) \\
\text { (1) }\end{array}$ & (1.1) & $(1.2)$ & (1.2) & $(0.8)$ & $(0.8)$ & (15.2) & (1.9) & (1.9) & (1.8) & (2.4) & $(2.5)$ & (1.6) & (1.6) \\
\hline & $13+$ & 12.7 & 16.2 & 7.3 & 28.3 & 21.4 & 10.0 & 1.3 & 2.8 & 11.7 & 11.9 & 11.8 & 30.2 & 19.8 & 11.9 & 2.7 & 0.2 \\
\hline & & $(9.2)$ & (1.3) & (1.4) & $(1.0)$ & $(1.7)$ & $(1.1)$ & $(0.4)$ & $(0.6)$ & (21.6) & $(2.8)$ & (2.8) & $(2.8)$ & (3.9) & (2.8) & $(1.4)$ & $(0.4)$ \\
\hline
\end{tabular}

Note: Standard errors, in parentheses, account for the sample design. 
Table A6: Family profiles for women in rural areas by migration status, origin, age at migration, and years of schooling

\begin{tabular}{lrrrrrrrr}
\multirow{2}{*}{$\begin{array}{c}\text { Years of } \\
\text { schooling }\end{array}$} & \multicolumn{10}{c}{\begin{tabular}{l} 
Non-migrants \\
\cline { 2 - 9 }
\end{tabular}} & $\begin{array}{c}\text { One } \\
\text { transition }\end{array}$ & Latest & $\begin{array}{c}\text { Early- } \\
\text { stop }\end{array}$ & $\begin{array}{c}\text { Family typology } \\
\text { Delay- } \\
\text { norm }\end{array}$ & Normative & Unstable & Earliest & $\begin{array}{c}\text { Early- } \\
\text { norm }\end{array}$ \\
\hline 0 to 4 & 5.7 & 3.0 & 4.6 & 7.1 & 11.6 & 14.4 & 22.8 & 30.7 \\
& $(2.6)$ & $(0.2)$ & $(0.1)$ & $(0.2)$ & $(0.2)$ & $(0.3)$ & $(0.4)$ & $(0.4)$ \\
5 to 8 & 9.2 & 3.0 & 7.8 & 7.6 & 21.3 & 15.7 & 14.5 & 20.9 \\
& $(4.3)$ & $(0.5)$ & $(0.3)$ & $(0.5)$ & $(0.5)$ & $(0.6)$ & $(0.6)$ & $(0.7)$ \\
9 to 12 & 9.2 & 5.6 & 12.2 & 16.0 & 26.5 & 16.2 & 5.8 & 8.5 \\
& $(7.9)$ & $(1.0)$ & $(0.8)$ & $(1.1)$ & $(1.3)$ & $(1.3)$ & $(0.8)$ & $(1.0)$ \\
$13+$ & 17.9 & 8.4 & 4.9 & 26.4 & 22.3 & 13.6 & 1.5 & 4.9 \\
& $(15.3)$ & $(2.5)$ & $(1.8)$ & $(1.4)$ & $(2.8)$ & $(2.2)$ & $(0.8)$ & $(1.4)$ \\
\hline
\end{tabular}

\begin{tabular}{|c|c|c|c|c|c|c|c|c|c|c|c|c|c|c|c|c|c|}
\hline \multirow{2}{*}{\multicolumn{2}{|c|}{$\begin{array}{c}\text { Age at } \\
\text { migration } \\
\text { and years of } \\
\text { schooling }\end{array}$}} & \multicolumn{8}{|c|}{ Migrants of urban origin } & \multicolumn{8}{|c|}{ Migrants of rural origin } \\
\hline & & \multirow{2}{*}{$\begin{array}{r}\begin{array}{c}\text { One } \\
\text { transition }\end{array} \\
2.8\end{array}$} & \multirow{2}{*}{$\begin{array}{r}\text { Latest } \\
1.7\end{array}$} & \multirow{2}{*}{$\begin{array}{r}\begin{array}{c}\text { Early- } \\
\text { stop }\end{array} \\
6.0\end{array}$} & \multirow{2}{*}{$\begin{array}{r}\begin{array}{l}\text { Delay- } \\
\text { norm }\end{array} \\
4.3\end{array}$} & \multirow{2}{*}{$\begin{array}{r}\text { Normative } \\
9.3\end{array}$} & \multirow{3}{*}{$\begin{array}{r}\text { Unstable } \\
12.1\end{array}$} & \multirow{3}{*}{$\begin{array}{r}\text { Earliest } \\
39.4\end{array}$} & \multirow{3}{*}{$\begin{array}{r}\begin{array}{l}\text { Early- } \\
\text { norm }\end{array} \\
24.5 \\
(1.8)\end{array}$} & \multirow{3}{*}{$\begin{array}{r}\begin{array}{c}\text { One } \\
\text { transition }\end{array} \\
3.0 \\
(9.2)\end{array}$} & \multirow{3}{*}{$\begin{array}{r}\text { Latest } \\
1.6 \\
(0.5)\end{array}$} & \multirow{3}{*}{$\begin{array}{r}\begin{array}{l}\text { Early- } \\
\text { stop }\end{array} \\
4.6 \\
(0.3)\end{array}$} & \multirow{2}{*}{$\begin{array}{r}\begin{array}{l}\text { Delay- } \\
\text { norm }\end{array} \\
2.3\end{array}$} & \multirow{3}{*}{$\begin{array}{r}\text { Normative } \\
9.7\end{array}$} & \multirow{3}{*}{$\begin{array}{r}\text { Unstable } \\
12.6 \\
(0.9)\end{array}$} & \multirow{3}{*}{$\begin{array}{r}\text { Earliest } \\
39.2\end{array}$} & \multirow{2}{*}{$\begin{array}{r}\begin{array}{l}\text { Early- } \\
\text { norm }\end{array} \\
27.0\end{array}$} \\
\hline $\begin{array}{l}<18 \\
\end{array}$ & 0 to 4 & & & & & & & & & & & & & & & & \\
\hline & & $(14.6)$ & $(0.7)$ & $(0.5)$ & (1.0) & $(0.9)$ & & & & & & & $(0.6)$ & & & & $(1.2)$ \\
\hline & 5 to 8 & 5.2 & 1.0 & 15.9 & 3.6 & 15.9 & 17.0 & 19.8 & 21.7 & 4.9 & 1.4 & 9.9 & 2.5 & 20.8 & 16.9 & 25.5 & 18.1 \\
\hline & & (18.9) & (1.5) & $(0.7)$ & (2.5) & (1.3) & (2.6) & (2.8) & (2.9) & (14.8) & (1.3) & $(0.7)$ & (1.8) & $(0.9)$ & (2.3) & (2.6) & $(2.3)$ \\
\hline & 9 to 12 & 3.8 & 5.1 & 7.0 & 14.4 & 21.0 & 23.2 & 19.7 & 5.8 & 1.9 & 0.7 & 21.8 & 7.2 & 26.2 & 17.8 & 14.7 & 9.6 \\
\hline & & (28.5) & $(2.2)$ & (2.6) & (3.0) & (4.1) & (4.9) & (4.6) & $(2.7)$ & (32.3) & $(2.0)$ & (1.2) & (5.9) & (3.7) & (5.4) & $(5.0)$ & $(4.2)$ \\
\hline & $13+$ & 7.7 & 3.8 & 2.9 & 24.2 & 32.8 & 25.9 & 0.2 & 2.5 & 20.5 & 1.6 & 6.5 & 13.0 & 32.0 & 21.2 & 3.2 & 2.1 \\
\hline & & (42.0) & (5.3) & (3.8) & (3.3) & (8.4) & (8.6) & $(0.8)$ & $(3.1)$ & (62.3) & (11.7) & (3.7) & (7.2) & $(9.8)$ & (11.9) & $(5.1)$ & $(4.2)$ \\
\hline $19-24$ & 0 to 4 & 2.3 & 1.9 & 5.6 & 4.0 & 15.0 & 17.0 & 21.4 & 32.8 & 2.9 & 1.2 & 4.5 & 2.3 & 17.7 & 14.5 & 15.2 & 41.7 \\
\hline & & (11.4) & $(0.6)$ & $(0.6)$ & $(0.9)$ & $(0.8)$ & (1.5) & (1.7) & (1.9) & (6.2) & $(0.4)$ & $(0.3)$ & $(0.5)$ & $(0.4)$ & $(0.8)$ & $(0.8)$ & $(1.2)$ \\
\hline & 5 to 8 & 2.0 & 1.3 & 7.8 & 6.4 & 23.2 & 19.3 & 10.4 & 29.7 & 1.3 & 0.2 & 8.3 & 5.3 & 28.6 & 21.6 & 11.2 & 23.6 \\
\hline & & (13.5) & $(0.8)$ & $(0.6)$ & (1.5) & (1.4) & (2.2) & (1.7) & (2.6) & (11.2) & $(0.6)$ & $(0.2)$ & (1.4) & $(1.1)$ & $(2.1)$ & (1.6) & $(2.2)$ \\
\hline & 9 to 12 & 3.7 & 1.9 & 5.4 & 12.0 & 48.7 & 17.4 & 4.6 & 6.2 & 2.9 & 0.7 & 13.3 & 3.2 & 47.1 & 21.0 & 3.6 & 8.2 \\
\hline & & (16.2) & (1.5) & (1.1) & (1.8) & (2.6) & (3.1) & (1.7) & $(2.0)$ & (21.4) & (1.8) & $(0.9)$ & (3.6) & (1.9) & (4.4) & $(2.0)$ & $(2.9)$ \\
\hline & $13+$ & 2.2 & 5.9 & 5.5 & 10.5 & 37.0 & 30.5 & 2.3 & 6.2 & 2.1 & 11.6 & 7.5 & 13.7 & 44.3 & 20.3 & 0.2 & 0.3 \\
\hline & & (31.8) & $(2.2)$ & (3.6) & (3.5) & (4.7) & $(7.1)$ & $(2.3)$ & (3.7) & (43.0) & $(3.1)$ & $(6.8)$ & (5.6) & (7.3) & $(8.6)$ & $(1.0)$ & $(1.1)$ \\
\hline 25-30 & 0 to 4 & 3.3 & 0.6 & 3.3 & 14.2 & 11.6 & 17.2 & 26.4 & 23.4 & 1.8 & 2.2 & 5.8 & 12.2 & 12.2 & 17.7 & 21.1 & 27.0 \\
\hline & & (13.9) & $(0.8)$ & $(0.4)$ & $(0.8)$ & (1.5) & (1.7) & $(2.0)$ & (1.9) & $(8.1)$ & $(0.4)$ & $(0.4)$ & $(0.6)$ & $(0.9)$ & $(1.0)$ & $(1.1)$ & $(1.2)$ \\
\hline & 5 to 8 & 2.4 & 2.3 & 6.2 & 22.0 & 17.0 & 18.0 & 15.2 & 16.9 & 3.0 & 3.9 & 6.7 & 15.5 & 22.0 & 20.4 & 11.9 & 16.6 \\
\hline & & $(17.0)$ & $(1.0)$ & $(1.0)$ & (1.5) & (2.7) & $(2.5)$ & $(2.3)$ & (2.4) & (13.5) & $(1.0)$ & (1.1) & (1.4) & $(2.0)$ & $(2.2)$ & (1.8) & $(2.1)$ \\
\hline & 9 to 12 & 5.6 & 4.4 & 5.0 & 19.7 & 30.8 & 24.9 & 4.7 & 4.9 & 9.8 & 2.8 & 12.1 & 27.7 & 19.0 & 15.6 & 8.8 & 4.2 \\
\hline & & (21.6) & (2.3) & $(2.0)$ & $(2.2)$ & $(4.0)$ & $(4.3)$ & $(2.1)$ & $(2.2)$ & (30.1) & $(3.5)$ & $(2.0)$ & (3.8) & (5.3) & $(4.3)$ & (3.3) & $(2.4)$ \\
\hline & $13+$ & 13.7 & 10.1 & 5.3 & 39.7 & 14.7 & 8.2 & 5.2 & 3.3 & 8.2 & 13.3 & 13.5 & 32.6 & 20.9 & 11.2 & 0.2 & 0.2 \\
\hline & & (37.2) & $(4.5)$ & $(4.0)$ & (2.9) & (6.4) & (3.6) & $(2.9)$ & $(2.3)$ & (48.8) & (5.4) & (6.7) & (6.8) & (9.3) & (6.2) & $(0.9)$ & $(1.0)$ \\
\hline$>30$ & 0 to 4 & 3.6 & 3.4 & 5.7 & 5.5 & 12.3 & 19.1 & 30.1 & 20.3 & 3.8 & 4.3 & 3.9 & 8.1 & 8.3 & 17.9 & 27.7 & 26.0 \\
\hline & & $(9.7)$ & $(0.6)$ & $(0.6)$ & $(0.7)$ & $(0.7)$ & (1.3) & (1.5) & (1.3) & $\begin{array}{l}7.0) \\
(7.0)\end{array}$ & $(0.4)$ & $(0.4)$ & $(0.4)$ & $(0.5)$ & $(0.7)$ & $(0.9)$ & $(0.8)$ \\
\hline & 5 to 8 & 6.7 & 5.8 & 8.3 & 8.1 & 15.4 & 22.3 & 17.8 & 15.6 & 5.4 & 6.8 & 8.5 & 12.5 & 18.3 & 18.4 & 15.6 & 14.5 \\
\hline & & (14.3) & (1.3) & $(1.2)$ & (1.4) & (1.4) & $(2.1)$ & $(2.0)$ & (1.9) & (11.1) & $(1.0)$ & $(1.1)$ & (1.2) & (1.4) & (1.7) & (1.6) & $(1.5)$ \\
\hline & 9 to 12 & 9.7 & 10.1 & 9.5 & 14.4 & 18.3 & 23.3 & 5.8 & 8.9 & 15.1 & 8.9 & 9.3 & 18.3 & 22.7 & 17.9 & 4.0 & 4.0 \\
\hline & & (18.5) & $(2.1)$ & $(2.2)$ & $(2.1)$ & $(2.5)$ & $(3.0)$ & (1.7) & $(2.0)$ & (20.5) & $(3.1)$ & (2.4) & $(2.5)$ & (3.3) & (3.3) & $(1.7)$ & $(1.7)$ \\
\hline & $13+$ & 15.5 & 10.7 & 7.7 & 29.4 & 15.4 & 17.5 & 2.0 & 1.7 & 10.1 & 20.8 & 4.4 & 27.3 & 22.5 & 13.0 & 0.2 & 1.7 \\
\hline & & (21.5) & (2.8) & $(2.4)$ & (2.1) & (3.5) & (3.0) & (1.1) & $(1.0)$ & (35.6) & (4.5) & (6.0) & (3.1) & (6.6) & (5.0) & $(0.7)$ & $(1.9)$ \\
\hline
\end{tabular}

Note: Standard errors, in parentheses, account for the sample design. 